\title{
Working
}

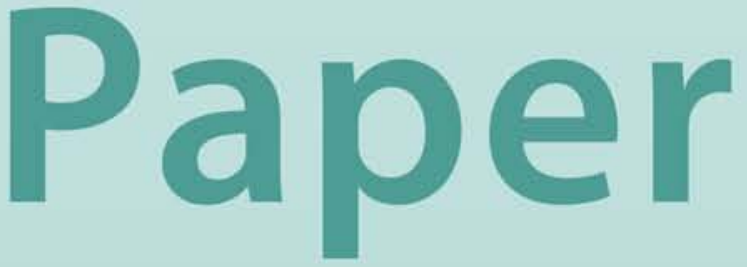


Global Aging and Fiscal Policy with International Labor Mobility: A Political Economy Perspective

\author{
Mehmet Serkan Tosun
}




\title{
IMF Working Paper
}

\author{
Research Department
}

\section{Global Aging and Fiscal Policy with International Labor Mobility: A Political Economy Perspective}

\author{
Prepared by by Mehmet Serkan Tosun ${ }^{1}$ \\ Authorized for distribution by Tim Callen
}

July 2005

\begin{abstract}
This Working Paper should not be reported as representing the views of the IMF. The views expressed in this Working Paper are those of the author(s) and do not necessarily represent those of the IMF or IMF policy. Working Papers describe research in progress by the author(s) and are published to elicit comments and to further debate.

This paper uses an overlapping generations model with international labor mobility and a politically responsive fiscal policy to examine aging in developed and developing regions. Migrant workers change the political structure composed of young and elderly voters in both labor-receiving and labor-sending countries. Numerical simulations show that the developed region benefits more from international labor mobility through the contribution of migrant workers as laborers, savers, and voters. The developing region experiences significant growth in all specifications but benefits more under international capital mobility. Restricting political participation of migrant workers in the developed region produces inferior growth results.
\end{abstract}

JEL Classification Numbers: E62, F21, F22, F43, H30, J10

Keywords: population aging, overlapping generations, endogenous fiscal policy, international labor mobility, international capital mobility

Author(s) E-Mail Address: metosun@mail.wvu.edu

\footnotetext{
${ }^{1}$ Mehmet Tosun is a Research Assistant Professor at the Bureau of Business and Economic Research, West Virginia University. This paper is based partly on work done by the author during his visit to the IMF. Partial funding was provided by the Kennedy-Vanscoy Fund for Faculty Development in the College of Business and Economics, West Virginia University. The author wishes to thank Nicoletta Batini and Tim Callen for helpful discussions and Ben Sutton for research assistance. George Hammond, Douglas J. Holtz-Eakin, Mary E. Lovely, and Serdar Sayan provided helpful comments on an earlier version of this paper.
} 


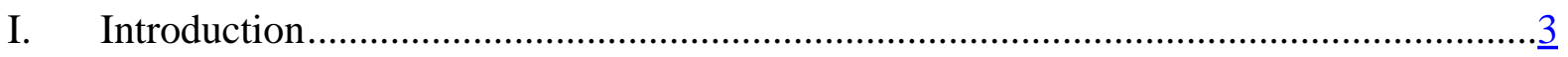

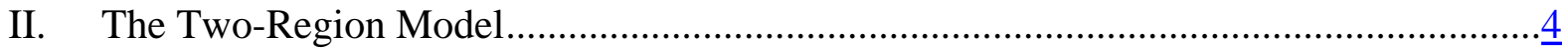

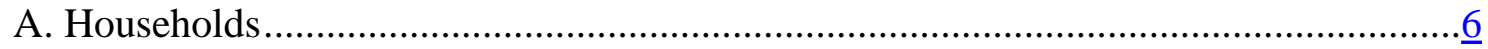

B. Political Process of Fiscal Policy .................................................................... $\underline{8}$

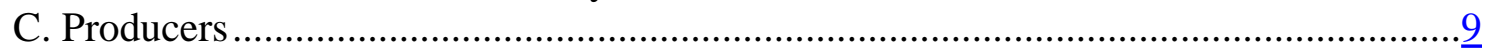

D. International Goods Market Equilibrium and Labor Flows...................................10

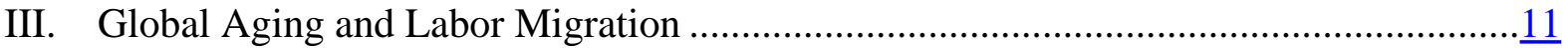

A. Population Projections and Simulation Description ..........................................11

B. Full Labor Mobility Simulation Results .........................................................

C. Model Comparisons and Labor Mobility Scenarios .............................................. 16

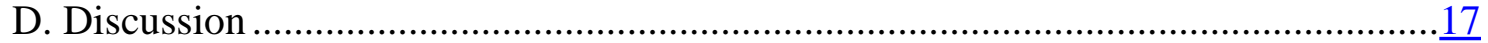

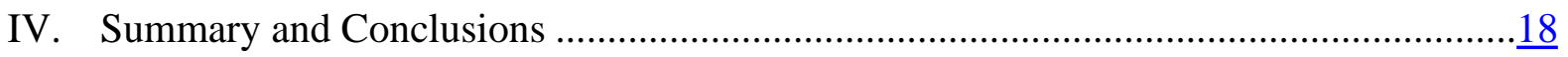

Tables

1. Education Spending and Migration in Developed and Developing Regions ...................... 20

2. Comparisons with Alternative Factor Mobility Models ................................................. $\frac{21}{23}$

3. Comparison of Predicted and Actual Labor Flows to Developed Region...........................23

Figures

1. Population Growth Rates in Developed and Developing Regions .................................. 24

2. Composition of the Change in the Number of Workers in the Developed Region ..............24

3. Ratio of Immigrant Labor to Developed Region Population............................................25

4. Composition of the Change in the Number of Workers in the Developing Region ............. 25

5. Change in Capital Stock Per Worker in Developed and Developing Regions .....................26

6. Change in Human Capital Per Worker in Developed and Developing Regions .................26

7. Change in Education Tax Rate in Developed and Developing Regions ............................27

8. Change in Education Spending Per Worker in Developed and Developing Regions ..........27

9. Change in Income Per Worker in Developed and Developing Regions.............................28

10. Change in Consumption of Young in Developed and Developing Regions .....................28

11. Change in Consumption of Old in Developed and Developing Regions .........................29

12. Change in Sum of Young and Old Consumption in Developed and Developing

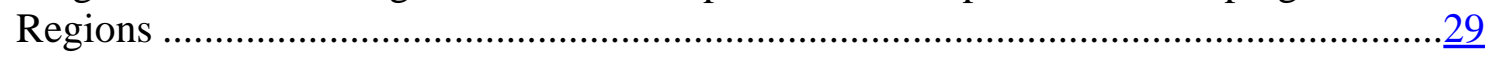

Appendix: The Effect of Increasing Dependency Ratio on the Ability Level of the Median Voter ..................................................................................................... 30

Appendix Table 1: List of Economies Used in Population Projections..................................

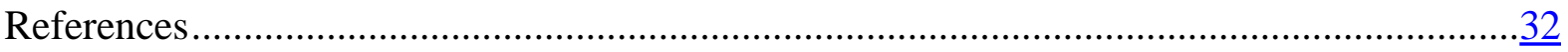




\section{INTRODUCTION}

Population aging has become a global phenomenon. Population projections show that the world median age will rise from 26.4 in 2000 to 36.8 in 2050 (United Nations, 2002a). While recent focus has been on population aging in advanced economies, developing countries are not far from the aging trend. The United Nations projections indicate that oldage dependency ratios ${ }^{2}$ in developed and developing regions will increase approximately by 4 percent and 70 percent between 2050 and 2100, respectively. By 2150, the difference between the old-age dependency ratios of the two regions will be quite small ${ }^{3}$. Thus, population aging is not confined to advanced economies; sooner or later populations of all nations will age. Heller (2003, p.13) gives a striking example by noting that the share of the elderly population in the United Arab Emirates is expected to rise from 2 percent to 28 percent by 2050 .

An important consequence of population aging is increasing fiscal pressure through higher government spending on social security, health care, and other welfare programs for the elderly. ${ }^{4}$ This may mean lower government spending for other programs that primarily benefit the young. The link between increasing political power of the elderly and government spending on such programs as education has been examined by Gradstein and Kaganovich (2004), Holtz-Eakin, Lovely, and Tosun (2004), and Razin, Sadka, and Swagel (2002). Since education is a major input to human capital accumulation, aging is expected to have significant growth consequences. Aging has also been analyzed in open economy by Cutler, et al. (1990), Börsch-Supan (1996), Kenc and Sayan (2001), Elmendorf and Sheiner (2000), Jelassi and Sayan (2004), Tosun (2001, 2003), and Van Groezen and Leers (2000). This literature shows the significance of the international spillover effects of aging. While there is a growing literature analyzing the link between population aging and international capital mobility, only few studies examined aging with labor migration (Leers, Meijdam, and Verbon, 2004; Storesletten, 2000). In a dynamic model with international capital mobility only, wage rates do not necessarily equalize between countries in all periods of their transition to the long run steady state. This implies that, when allowed, labor will move to the country with the higher standard of living. This highlights the need for an analysis of aging in an open economy framework with international labor mobility. Galor (1992) argued that capital and labor have asymmetric characteristics. Labor mobility has a dual effect in the

\footnotetext{
${ }^{2}$ Old-age dependency ratio is the proportion of population aged 65 and older to population aged 15 to 64 .

${ }^{3}$ A medium fertility scenario shows that in 2150 the old-age dependency ratios will be 0.47 and 0.43 for the developed and developing regions, respectively.

${ }^{4}$ See Heller (2003) and CSIS (2002) for recent discussions on the fiscal implications of global aging.
} 
sense that it exhibits the characteristics of capital mobility as well. Young migrant workers contribute to the economy, both as laborers and as savers. What the aging literature has not addressed is that, when allowed to vote, migrant workers will change the political structure composed of young and elderly voters in both labor-receiving and labor-sending countries. In a majority voting mechanism for fiscal policy decisions, political shifts resulting from labor migration may have sizable effects on government programs, and in turn may have strong growth effects. This paper uses a two-region, two-period overlapping generations model with international labor mobility and a politically responsive fiscal policy to examine the growth effects of the aging trend in developed and developing countries. The paper contributes to the literature on the economic effects of population aging in two major ways. First, it brings out the political economy of aging through the aging-education-human capital link. The paper argues that this is particularly important in the context of international labor mobility with young migrant workers participating in the political system of advanced economies. Second, the paper examines the significance of factor mobility as a policy choice by comparing the labor mobility model to an alternative open economy model with international capital mobility.

The paper is structured as follows. The next section gives a description of a tworegion, two-period overlapping generations model with international labor mobility. This is followed by a transition analysis in Section III that shows results from various numerical simulation exercises. The last section presents a summary and concluding remarks.

\section{THE TWO-REgION MODEL}

The model builds on a two-period overlapping generations model first developed by Diamond (1965). ${ }^{5}$ To examine open economy issues, the standard framework is extended to a two-region model with international labor mobility similar to Galor $(1986,1992)$ and Crettez et al. (1996, 1998). ${ }^{6}$ Another major extension is the modeling of fiscal policy decisionmaking through a political process.

Recent discussions on population aging have noted the potential generational conflict arising from the need to share society's resources between non-working elderly and the younger working population. It is argued that increasing the number of elderly voters could render changes in public expenditure patterns in favor of the elderly. This, in turn, could trigger serious generational conflict regarding government programs that enhances the productivity of the working young. One good example of this is government spending on public education. For simplicity, the productivity-enhancing public program will be referred

\footnotetext{
${ }^{5}$ However, the earliest overlapping generations models are described by Allais (1947) and Samuelson (1958). Children are not modeled in a two-period model.

${ }^{6}$ A two-country model with international capital mobility is shown by Buiter (1981).
} 
to as "education" throughout the text. ${ }^{7}$ The goal is to highlight the strong link between this type of government spending and human capital accumulation, which is considered to be one of the most important avenues for economic growth.

Empirical studies, particularly from the United States, show the significance of the political economy consideration of the relationship between population aging and education spending. Among the earlier studies, Button (1992) suggests that generational conflict is quite apparent on education issues by examining the voting behavior of the elderly in tax referenda in six Florida counties. Deller and Walzer (1993) found weaker evidence of such generational conflict based on a survey of residents in rural Illinois. Poterba (1997) provided empirical evidence using state-level data that older citizens prefer lower levels of public spending for education, an expenditure that primarily benefits the young. A recent study by Harris, Evans, and Schwab (2001) confirmed this finding using school-district-level data, however with a smaller estimated impact than Poterba's estimates. While the 2004 AARP Aging American Voter Survey indicates that a majority of older people support federal government's responsibility in educating young people, the same survey shows that a large group of older people also became more conservative in issues such as government spending, bureaucracy, and taxes. ${ }^{8}$

Given the expected future aging trends in both developed and developing countries, generational conflict in education spending could become even more prevalent. Modeling generational conflict in education is also important when we consider immigration. Table 1 provides basic statistics on immigration and education spending. It shows that high-income (developed) countries that had positive net migration rates between 1995 and 2000 indeed had both higher average education spending per capita and higher percentage increase in education spending per capita in this period compared to both less developed regions and least advanced economies. Among these advanced economies, the ones with the highest net migration rate also had a significantly higher increase in education spending than the ones with the lowest net migration rate. Hence, aging-education link may provide useful insight in a study on population aging and international labor mobility. To make the political process of fiscal policy determination for public education rich, interesting, yet tractable, a median-voter framework with voter heterogeneity is used. Voter heterogeneity is introduced by assuming a distribution of genetic ability levels for the working generation. The ability level of the individual will, in turn, determine the value she receives from public education. While the emphasis of the paper is political economy of education spending, a social security program is also introduced by having an exogenously fixed level of social security spending in the model. An income tax that is earmarked for social security adjusts through the periods to balance the social security budget. Thus, there are separate taxes for education and social

\footnotetext{
${ }^{7}$ It should be noted that any other government program that is directed towards increasing the labor productivity of the young could easily be used.

${ }^{8}$ See AARP (2004) for a summary of findings from this survey.
} 
security spending with voters deciding only on the education tax rate. ${ }^{9}$ For clarity, the model is presented for one region only. This is followed by a description of the two-region world equilibrium.

\section{A. Households}

Individuals live for two periods and seek to maximize a utility function based on discretionary consumption in the first and second period of their lives,

$$
U=\ln C_{j t}+\left(\frac{1}{1+\delta}\right) \ln C_{j t+1},
$$

here $j$ indexes individuals, $C_{j t}$ is consumption when young, $C_{j t+1}$ is consumption when old, and $\delta$ is the pure rate of time preference. The period-specific budget constraints in the first and the second periods are:

First period: $C_{j t}\left(a_{j}\right)+S_{j t}\left(a_{j}\right)=\left(1-\tau_{t}-\mu_{t}\right) w_{t} l_{t}\left(a_{j}\right)$

Second Period: $C_{j t+1}\left(a_{j}\right)=\left(1+\left(1-\tau_{t+1}-\mu_{t+1}\right) r_{t+1}\right) S_{j t}\left(a_{j}\right)$,

where $S_{j t}\left(a_{j}\right)$ is first period saving, $w_{t}$ is the wage rate individual $j$ faces, $l_{t}\left(a_{j}\right)$ is

effective labor, ${ }^{10}$ where $a_{j}$ is the ability level of individual $j, r_{t+1}$ is the rate of return to capital, $\tau_{t}$ is the rate of income taxation that is applied to both capital and labor income. This tax is used entirely to finance education spending. An additional tax $\left(\mu_{t}\right)$ is also applied to capital and labor income to finance social security spending by the government.

It is assumed that there is a continuous distribution of abilities that is replicated in each new generation. The ability level of individual $j$ is indexed by $a_{j}$, which ranges from 0 to 1 . The density function of abilities is denoted by $f(a)$ where by definition:

\footnotetext{
${ }^{9}$ The political process is modeled through a median voter framework because the conditions for the median voter theorem are satisfied. The choice of voters is over a single dimension since the preferred education tax rate is the only choice variable, and the voter preferences are single peaked. The property of single-peakedness has been demonstrated to ensure existence of a voting equilibrium (Black 1948).

${ }^{10}$ Here, young supplies one unit of time to the economy. Note that making the allocation of time between "schooling” and supplying labor endogenous does not change this analysis.
} 


$$
\int_{0}^{1} f(a) d a=1
$$

Human capital is accumulated from the interaction of ability level $\left(a_{j}\right)$ of the individual and government spending per young $\left(g_{t}^{e}\right)$ on education:

$$
l_{t}\left(a_{j}\right)=\Phi\left[a_{j} g_{t}^{e}+1\right]^{\psi}
$$

where, $\Phi$ denotes an index on human capital efficiency and $\psi$ is a parameter indicating the return to human capital from the inputs $\left(a_{j}\right.$ and $\left.g_{t}^{e}\right) .{ }^{11}$ The form of the human capital function is chosen so that even individuals with the lowest ability $\left(a_{j}=0\right)$ will contribute to the economy in terms of human capital (see Holtz-Eakin, Lovely, and Tosun 2004). From the maximization of (1) subject to (2) and (4); we get the familiar first order condition:

$$
C_{j t}\left(a_{j}\right)=\frac{1+\delta}{\left(1+r_{t+1}\left(1-\tau_{t+1}-\mu_{t+1}\right)\right)} C_{j t+1}\left(a_{j}\right) .
$$

Using (5) and (2), we derive the optimal saving of an individual $j$ :

$$
S_{j t}\left(a_{j}\right)=\frac{1}{2+\delta}\left(1-\tau_{t}-\mu_{t}\right) w_{t} l_{t}\left(a_{j}\right)
$$

Saving of an individual depends on net labor earnings but it is independent of the interest rate. This is due to the Cobb-Douglas form of the utility function. Given (5) and (6), it is straightforward to derive consumption functions in each period:

$$
\begin{aligned}
& C_{j t}\left(a_{j}\right)=\frac{1+\delta}{2+\delta}\left(1-\tau_{t}-\mu_{t}\right) w_{t} l_{t}\left(a_{j}\right) \\
& C_{j t+1}\left(a_{j}\right)=\frac{\left(1+r_{t+1}\left(1-\tau_{t+1}-\mu_{t+1}\right)\right)\left(\left(1-\tau_{t}-\mu_{t}\right) w_{t} l_{t}\left(a_{j}\right)\right)}{2+\delta} .
\end{aligned}
$$

${ }^{11} \psi$ should be less than or equal to unity to prevent increasing returns from government spending. 


\section{B. Political Process of Fiscal Policy}

It is assumed that there is a predetermined level of social security spending. Thus the social security tax $\mu_{t}$ is simply determined by the government budget constraint $\left(\mu_{t} y_{t}=g_{t}^{s}\right)$, where $g_{t}^{s}$ is the social security spending per young person. ${ }^{12}$

However, the fiscal policy for education is determined through a political process for which a median-voter framework with voter heterogeneity is used. Voter heterogeneity is introduced by assuming a uniform distribution of genetic ability levels for the working generation. The ability level of the individual will, in turn, determine the value she receives from the public good.

The consumption and saving decisions, as seen above, depend on human capital, which is in turn determined by government spending (see equation 4). By plugging these into (1), we get the indirect utility function, which each voter maximizes, in determining his or her preferred tax rate, subject to the government budget constraint for this type of government spending $\left(\tau_{t} y_{t}=g_{t}^{e}\right) .{ }^{13}$ The preferred tax rate of individual $j$ when young is:

$$
\tau_{j t}\left(a_{j}\right)=\frac{a_{j} \psi y_{t}\left(1-\mu_{t}\right)-1}{(1+\psi) a_{j} y_{t}}
$$

Equation (8) is the tax rate each individual prefers based on her ability level. This preferred tax rate is increasing in both ability level $a_{j}$ and in income per young $y_{t}$ but decreasing in the social security tax $\mu_{t}$. Thus, the existence of a social security system depresses education spending through a lower preferred education tax rate. In addition, because the old do not derive any benefit from publicly provided education and there are no bequests in the model, they incur a cost without enjoying any benefits. Therefore, their preferred education tax rate will always be zero, regardless of their ability.

Total population in each period is $N_{t-1}+N_{t}$ where $N_{t}$ is composed of both newly born nationals and migrant workers. Given this, the median voter is defined by

\footnotetext{
${ }^{12}$ Social security spending consists of equal payments to elderly population to finance a programmed elderly consumption such as health care. This consumption is assumed to be separate from the discretionary consumption decision and therefore it is not shown as part of households' utility maximization depicted in equations (1) through (7).

${ }^{13}$ It is assumed in each period that government uses the entire revenue from this tax to finance the public good for all young equally, regardless of their ability level (Bearse, Glomm, and Ravikumar 2000).
} 


$$
N_{t-1}+N_{t} \int_{0}^{a_{m}} f(a) d a=\frac{N_{t-1}+N_{t}}{2},
$$

here $a_{m}$ is the ability level of the median voter.

In the absence of migration, the median voter becomes a person with lower ability when population ages. In turn, the preferred tax rate of the median voter is lower. In other words, with population aging older people need fewer young voters to form a majority. Since these young voters are the ones at the lower end of the ability distribution, they prefer lower taxes than higher ability people because their return from public education is lower.

When labor migration is allowed, an aging country will experience an inflow of labor due to a higher wage rate than the rest of the world. This will change the age distribution of population in favor of the young generation. The identity of the median voter will be different from the case without migration (see the Appendix). Now, the ability of the median voter will be higher compared to median voter's ability in the case without migration. However, whether the ability of median voter with migration can be greater than the preaging level is uncertain. ${ }^{14}$

\section{Producers}

Each country produces a single good using a Cobb-Douglas production technology.

$$
Y_{t}=\Lambda K_{t}^{\alpha} H_{t}^{1-\alpha}
$$

here $\Lambda$ is the productivity index, $K$ is capital stock and $H$ is aggregate supply of human capital. The aggregate supply of human capital is:

$$
H_{t}=N_{t} \int_{0}^{1} l(a) f(a) d a .
$$

Human capital per worker, using (4) and (11), is

$$
h_{t}=\Phi \int_{0}^{1}\left(a g_{t}+1\right)^{\psi} f(a) d a \text {. }
$$

Competitive factor markets require that real wage and interest rates are equal to the marginal products of labor and capital respectively. Therefore, factor demand equations are:

\footnotetext{
${ }^{14}$ In reality, there are barriers to labor migration that may rule out such a case.
} 


$$
\begin{aligned}
& w_{t}=(1-\alpha) \Lambda\left(\frac{k_{t}}{h_{t}}\right)^{\alpha} \\
& r_{t}=\alpha \Lambda\left(\frac{k_{t}}{h_{t}}\right)^{\alpha-1} .
\end{aligned}
$$

Here, $k_{t}=K_{t} / N_{t}$ and $h_{t}=H_{t} / N_{t}$ are capital stock per worker and human capital per worker, respectively.

Using (6) and (12), saving per worker can be expressed as

$$
S_{t}=\left(\frac{1}{2+\delta}\right)\left(1-\tau_{t}-\mu_{t}\right) w_{t} \Phi \int_{0}^{1}\left(a g_{t}+1\right)^{\psi} f(a) d a
$$

\section{International Goods Market Equilibrium and Labor Flows}

In the absence of international capital mobility, capital market equilibrium requires that saving in each period equals to accumulated capital in the following period. Capital market equilibrium conditions for each region can be depicted as

$$
\begin{aligned}
& k_{t+1}^{A}=\frac{N_{t}^{A} S_{t}^{A}}{N_{t+1}^{A}} \\
& k_{t+1}^{B}=\frac{N_{t}^{B} S_{t}^{B}}{N_{t+1}^{B}},
\end{aligned}
$$

where, superscripts $A$ and $B$ denote regions.

To close the dynamic model, international labor market equilibrium must be specified. For simplicity, I assume that there is perfect international labor mobility. ${ }^{15}$ International labor market equilibrium requires

$$
N_{t+1}^{A}+N_{t+1}^{B}=\left(1+\eta_{t+1}^{A}\right) N_{t}^{A}+\left(1+\eta_{t+1}^{B}\right) N_{t}^{B}
$$

${ }^{15}$ A recent study by National Research Council shows that total stock of migrants increased quite dramatically in late 1980s and early 1990s (see National Research Council, 2000, pp. 157-59). In addition, in my model one period corresponds to 30 years, which makes perfect labor mobility a viable assumption. 
where, $\eta_{t+1}^{A}$ and $\eta_{t+1}^{B}$ are the population growth rates in region $\mathrm{A}$ and region $\mathrm{B}$, respectively. Labor income is taxed where income is earned. Thus, source based income taxation is used for both regions. ${ }^{16}$ This implies that net-of-tax wage rates are equalized in equilibrium. Therefore, the international labor flow constraint is:

$$
w_{t+1}^{A} h_{t+1}^{A}\left(1-\tau_{t+1}^{A}-\mu_{t+1}^{A}\right)=w_{t+1}^{B} h_{t+1}^{B}\left(1-\tau_{t+1}^{B}-\mu_{t+1}^{B}\right) .
$$

It is assumed that only the members of the young generation moves between regions. Both regions are assumed to have "uniform" ability distributions, which mean that migration does not have any effect on the ability distribution in these regions. ${ }^{17}$

The model incorporates the interaction of household behavior, firm behavior, political process, and international labor flows. In the model explained above, a decrease in the population growth rate can affect labor flows and capital accumulation in two ways. First, it can affect "directly" by causing fewer workers in the economy, which leads to higher marginal product of labor, and thereby inducing labor inflows, ceteris paribus. Second, it can also affect "indirectly" through endogenous fiscal policy by changing the identity of the median voter. As a result of the aging trend, median voter becomes a lower ability person that votes for a lower tax rate.

\section{Global Aging AND LABor Migration}

\section{A. Population Projections and Simulation Description}

Simulations in this section are based on the population projections for developed and developing countries derived from the 2002 revision of the "World Population Prospects" published by the United Nations (United Nations, 2002a). The two world regions consist of 28 developed and 141 developing countries. The list of these developed and developing countries are given in Appendix Table 1 and the population growth rates implied by the projections are shown in Figure 1. The simulations will be shown for two 30-year periods, 2000-30 and 2030-60 and for the entire period 2000-60. The average population growth rates for the 1970-2000 period are used as a starting point. The population growth

\footnotetext{
${ }^{16}$ Under a source system, labor income is taxed where income is earned. The model tax treaties of the Organization for Economic Cooperation and Development (OECD) and the United Nations both give source countries the first rights to tax income accrued within their borders.

${ }^{17}$ A more realistic case is allowing for migration of workers that have certain abilities (unskilled vs. skilled). However, this would conflict with the uniform ability distribution which assumes that ability levels in the distribution are chosen at random.
} 
rate in advanced economies decreased from an initial annual average rate of 0.8 percent to 0.67 percent for the $2000-2030$ period and then to 0.38 percent for the $2030-60$ period. In developing countries, this rate goes down from an initial annual average rate of 2.47 percent to 1.39 percent for the 2000-30 period and then to 1.27 percent for the 2030-2060 period.

The elasticity of output with respect to capital input is set equal to one-third ( $\alpha=0.33) .{ }^{18}$ The annual rate of time preference is chosen to be 4 percent. ${ }^{19}$ The two parameters, the rate of time preference in the utility specification and the population growth rate, are adjusted to the length of the model period (30 years). In the simulations, the ability level, $a$, is assumed to be distributed uniformly on the interval $[0,1]$.

As mentioned in Section II, social security spending $\left(g_{t}^{s}\right)$ is exogenously set in the model. For simulations, social security expenditure for the developed and developing economies is compiled for the year 2000 using Government Finance Statistics published by the International Monetary Fund (2003). For simplicity, social security spending is assumed to grow in the future by the growth rate in population aged 65 and over. The United Nations population projections mentioned above enabled the derivation of social security spending for the periods 2000-30 and 2030-60.

A critical parameter in the model is the elasticity of human capital with respect to government spending on education and ability level $(\psi)$. Laitner (2000b) used a human capital function that is similar to (4) and set his human capital elasticity with respect to education equal to 0.1967 . Based on an initial value of the ability of the median voter, Laitner's estimate corresponds approximately to $\psi=0.4$ in our model. However, a study by Psacharopoulos (1985) estimated a significantly higher rate of return to education for low income and developing countries compared to advanced economies. Hence, $\psi=0.5$ is chosen as a compromise given Laitner's estimate and the large group of developing countries used in population projections. ${ }^{20}$

18 This elasticity estimate is consistent with the data from the United States. See Laitner (2000a) for an argument.

${ }^{19}$ Caldwell and others (1999) argue that a premium of riskiness should be added to the widely used 2 percent rate. They use 3.5 percent as the discount rate which is the real safe return on indexed treasury bonds. See Coronado, Fullerton, and Glass (2000) for a recent argument on the variety of discount rates used in studies of social security. They assert that the selection of discount rates ranges between 2 to 5 percent.

${ }^{20}$ See Holtz-Eakin, Lovely, and Tosun (2004) for a sensitivity analysis on this parameter. 


\section{B. Full Labor Mobility Simulation Results}

In line with the model presented in Section II, the full labor mobility simulation has perfect international labor mobility with migrant labor participating in the political system. Based on the population projections mentioned above, labor migrates from the developing region to the developed region. Figures 2 and 4 show this in reference to the change in the number of workers in both regions. Figure 2 shows that immigration of labor is a major component of the growth in the number of workers in advanced economies. Labor immigration makes up 46 percent of the 41.1 percent growth between 2000 and 2030, and 61 percent of the 40 percent growth between 2030 and 2060. It accounts for more than half (56 percent) of the labor growth in advanced economies between 2000 and 2060. Figure 3 shows how large the immigrant labor is relative to developed region population in 2000 . Simulations here show that the developed region receives increasing number of migrant labor through 2000-30 and 2030-60 periods. Overall, the developed region receives 29 percent of its 2000 population between 2000 and 2060. This also amounts to 48 percent of its workingage population.

On the other hand, developing countries send labor to the developed region and thus experience lower domestic labor growth. However, Figure 4 shows that this loss in labor growth is still a relatively small portion of the overall labor growth. For example, out of the 51.3 percent labor growth that would have been seen in the developing region between 2000 and 2030, 11.5 percent was lost due to out-migration of labor, leaving this region with a net 40 percent growth.

Figure 5 shows that this labor movement leads to opposite changes in capital stock per worker in developed and developing regions between 2000 and 2030. The influx of labor into the developed region does not translate into capital growth in that period since capital stock is determined by saving in the previous period (1970-2000), leading to a decrease in that period's capital stock per worker. The developing region experiences a significant rise in the capital stock per worker since the capital stock in the period 2000-2030 is utilized by fewer workers. The contribution of new labor to the growth in the developed region shows itself in the next period with a modest 4.2 percent growth in capital stock per worker. While the developing region still exhibits a strong growth in capital stock per worker between 2030 and 2060, this is significantly smaller than the growth recorded between 2000 and 2030. This is mainly due to considerable population growth decrease (from 2.47 percent to 1.39 percent) in developing countries coupled with labor emigration between 2000 and 2030 leading to significant saving per worker and capital per worker increases. While this population loss gave an initial boost to the developing region in 2000-30, it eventually showed itself in lower capital growth in the 2030-2060 period. The outlook for the 60-year period from 2000 to 2060 shows a small overall decline in capital stock per worker in the developed region but a strong increase in the developing region.

The other important component of growth is the human capital accumulation. As shown in equations (4) and (12), human capital is a function of the government spending on education. Changes in human capital are shown first in Figure 6, which is followed by 
figures that show changes in the education tax rate and education spending. Figure 6 shows that the developed region fares much better in human capital worker between 2000 and 2030 with a 7.8 percent growth. This is mainly due to migrant labor offsetting the negative effect of a decrease in the median voter ability, which would mean lower support for education spending, caused by aging. On the other hand, the developing region suffers from losing labor to the developed world by having a slight decrease in the human capital per worker between 2000 and 2030. As the labor growth falls by about ten percentage points in the developed region between 2030 and 2060, human capital per worker also drops. The decrease in the labor growth in the developing region in the same period is significantly smaller compared to the developed region. In addition, as shown in Figure 8, education spending recovers in the developing region between 2030 and 2060, leading to increases in human capital per worker. Nevertheless, both regions experience an overall growth in human capital per worker during the 2000-60 period.

As mentioned above, the link between labor growth and human capital can be understood better with an examination of the changes in the education tax rate and education spending. These are shown in Figure 7 and Figure 8, respectively. As discussed in the political process of fiscal policy, aging causes median voter to become a lower ability person putting a downward pressure on the education tax rate. However, labor migration offsets this negative effect by increasing the number of young voters. The migrant workers do not only contribute to domestic production but they also participate in the political system by voting for fiscal policy decisions. Since they are young, they change the political scene in favor of the young generation. Thus, with labor migration the choice of the tax rate changes in favor of the young voters despite the aging trend. Figure 7 shows this for the developed region between 2000 and 2030. The education tax rate increases considerably in the developed region while it falls quite dramatically in the developing region. However, the education tax rate decreases in the developed region in the following period as labor growth diminishes. The developed region experiences an overall increase in the education tax rate between 2000 and 2060 while the developing region records a significant decrease ${ }^{21}$ Changes in education spending in Figure 8 closely match the tax rate changes in Figure 7 and the human capital changes in Figure 6. However, education spending in the developing region increases between 2030 and 2060 and between 2000 and 2060 despite the tax rate decreases in these periods. This is mainly due to income growth in this region (examined below) that outweighs the education tax rate decreases.

\footnotetext{
${ }^{21}$ The results for the social security tax are not shown here but the rates do not change significantly across the periods mainly due to a fairly stable social security spending per young. Social security spending is forecasted outside the model and the social security tax rate is driven only by income changes.
} 
Results in Figures 5 and 6 for capital per worker and human capital per worker provide a good background for examining changes in income per worker. Figure 9 shows that both developed and developing regions exhibit income growth between 2000 and 2030 . While strong growth in human capital per worker in the developed region barely dominates a decrease in the capital stock per worker, considerable increase in the capital per worker in the developing region generates a much stronger income growth in this region. The developed region suffers from a decrease in human capital in the following period that leads to a decrease in income per worker. This region exhibits an overall decrease in income per worker for the entire period. On the other hand, the developing region benefits from growth in both capital per worker and human capital per worker, which leads to an income growth in all periods considered.

In addition to income per worker, consumption as a measure of welfare is examined in Figures 10 through 12. Figure 10 presents the change in the consumption of young in developed and developing regions. As shown in equation 7, consumption of a person when young depends on the net labor earnings. As also seen in equation 19, perfect labor mobility dictates that the net labor earning of a young worker gets equalized between the two regions. Since labor flows from the developing to the developed region, net labor earnings must have gone up in the developing region and it must have gone down in the developed region. This would increase consumption of young in the developing region and decrease it in the developed region. This is seen clearly in Figure 10. Since labor migration to the developed region occurs in both 2000-2030 and 2030-2060 periods, the same consumption pattern is observed in both periods and in the entire period from 2000 to 2060.

Old-age consumption, different from the young-age consumption, also depends on the net return on saving. The increase in the capital per worker in the developing region shown in Figure 5 depresses the interest rate in this region, leading to a decrease in the net return on saving. Figure 11 shows that this leads to a decrease in the old-age consumption between 2000 and 2030. The developed region experiences the opposite and has an increase in the old-age consumption in that period. In the following period, the old-age consumption in the developing region (developed region) increases (decreases) due to an increase (decrease) in the net saving income. However, the old-age consumption decreases in both regions for the entire period.

Figure 12 brings the results shown in Figures 10 and 11 together and show changes in the sum of consumptions, in a given period, of representative persons from young and old generations. The figure shows that the developing region experiences an increase in the sum of consumptions between 2030 and 2060 and for the entire period from 2000 to 2060. However, the developed region has an increase in the sum of consumptions only between 2000 and 2030. It has a slight overall decrease between 2000 and 2060. Finally, it is also possible to get a sum of the developed and developing region consumptions to see the change in the "world" consumption. While this is not explicitly shown in Figure 12, the growth in the sum of consumptions in the developing region dominates and the world consumption decreases only slightly between 2000 and 2030 but increases between 2030 and 2060 and between 2000 and 2060. 


\section{Model Comparisons and Labor Mobility Scenarios}

In this section, the full labor mobility model is compared to an alternative open economy model where capital is internationally mobile without international labor mobility. Further comparisons are also made using alternative assumptions about labor mobility and the political process of fiscal policy. The goal is to shed light on the choice of factor mobility in the presence of population aging. Table 2 presents simulation results for these comparisons. Results shown in Figure 2 and Figures 4 through 12 are reproduced in columns 1 and 2 of Table 2.

Columns 3 and 4 in Table 2 show that the capital mobility model produces significantly inferior outcomes for the developed region, in terms of the economic variables used in the analysis, compared to the full labor mobility model. It appears that labor flows to the developed region offset the adverse effect of population aging particularly on the human capital per worker. As explained earlier, migrant workers participate in the political process of fiscal policy by voting favorably for the education tax, leading to enhanced education spending and human capital in the developed region. The developing region exhibits strong capital and income growth throughout the periods under both full labor mobility and capital mobility (without labor mobility) models. In the capital mobility model without labor mobility, the developing region does not lose labor to the developed region and benefits from the inflow of capital from the developed region. In this model, capital inflows to the developing region enable this region to increase investment, production and income while at the same time retaining its young productive workers, voters and human capital. Thus, the capital mobility model (without labor mobility) produces more favorable results for the developing region compared to the full labor mobility model.

The next set of comparisons is between the full labor mobility model and variants of this model shown in columns (5) through (10) in Table 2. The first is the case where labor mobility is only allowed after 2030. This scenario considers the possibility that doors remain closed in the developed region until aging becomes an even bigger problem in the developed region. ${ }^{22}$ The results for this scenario in column (5) show that the developed region may fare slightly better particularly after 2030 if labor flow is delayed until 2030. This is mainly due to lower overall labor growth in the developed region. With this relatively low labor growth net return on labor does not decrease as much as in the full labor mobility model in column (1) leading to slightly better capital, human capital, income and consumption results.

The next scenario allows for free labor mobility but puts a constraint on the political participation of migrant labor in the developed region for the first period. This simulates an extended delay in the naturalization of foreign workers into the political system of a country. After a thirty-year delay, workers eventually become citizens with eligibility to vote.

\footnotetext{
${ }^{22}$ For example, in the United States, the effect of the baby boom generation retirement will not be seen for another decade.
} 
Column (7) shows that this scenario produces rather adverse outcomes for the developed region. These are mostly driven by sharp decreases in education tax rate, education spending and human capital per worker and show a strong contrast with results in column (1). With aging in the developed region, lack of young migrant votes for the education tax rate leads to a decrease in this tax rate such that the net labor earning differential between the regions can only be closed by a greater flow of labor from the developing to the developed region. ${ }^{23}$ This is the reason behind the interesting result of substantially high labor growth in the developed region. The results for the developing region in column (8) are quite similar to the ones in column (2) with slightly inferior results in the labor mobility model with delayed migrant voting.

Finally, the full labor mobility model is compared to an alternative model where education tax and spending are not determined through a political process but instead determined exogenously by the government. It is assumed here that the government fixes the education spending per worker. Results for the developed region in column (9) show that the direction of the income changes for 2000-30 and 2030-60 is reversed under this alternative model. Since there is no human capital feedback under this scenario, decreases in capital per worker between 2000 and 2030 decreases income per worker. However, as column (1) indicated, it is the human capital increase that leads to an increase in income per worker in this period under the labor mobility model. In addition, the labor mobility model in column (1) gives better consumption results (particularly the sum of young and old consumption) than the ones in column (9). Results for the developing region in column (10) show that the direction of changes in economic variables does not differ from the labor mobility model results in column (2). There are only slight changes in growth magnitudes.

\section{Discussion}

The simulation results presented show that the full labor mobility model is generally superior to other alternative models considered. Due to the perfect international labor mobility assumption, labor inflows to advanced economies implied by these results may be high by historical standards. To get a feel for the magnitude of these labor inflows, actual inflows of foreign population to advanced economies are compared to labor inflows predicted by the full labor mobility model. Table 3 presents this comparison using the simulation results in Figure 3 for the predicted labor inflows and actual foreign population inflows as reported by the OECD in 2000. The second row shows that predicted average annual number of labor migrants is fairly close to actual inflows of foreign population. It is even below the actual figure for the 2000-2030 period. The OECD distinguishes between foreign population inflows and foreign worker inflows. The third row in Table 3 shows the same ratio for the foreign worker inflows. In this case, the predicted average annual number of labor migrants is almost double the actual foreign worker inflows in 2000 for the 2000-30

${ }^{23}$ While not shown in Table 2, the decrease in the education tax rate is also balanced by a sharp increase in the social security tax rate. 
period, and it is about 2.7 times greater for the 2030-60 period. While the difference in this second comparison is fairly large, the predicted flows may well be consistent with dramatic population growth decreases expected in the advanced economies in the next 60 years.

Another issue that may be important in the interpretation of paper's results is that the benefits of labor inflows may be undermined by substantial transfers (other than education) to these migrants within the welfare system of advanced economies. While such transfers are not modeled in the paper, it is not certain how this would change the results presented in this paper. First, welfare transfers would be important if the magnitude of the labor inflows is indeed large. The comparison of predicted to actual foreign population inflows discussed above tells us that this magnitude may not necessarily be different from current actual inflows. Second, one can also imagine labor migrants in advanced economies voting for lower transfers (mainly social security) or lower social security taxes when they participate in the political system. Hence, this would put a counter pressure on welfare transfers. This paper focused only on the political economy of aging and education spending in order to highlight the importance of this link and also to attain simplicity in using the median voter model within the growth model. ${ }^{24}$

Finally, simulation results may be sensitive to a key parameter $(\psi)$ in the model, which indicates the return to human capital from the ability level and education spending. A closed economy study by Holtz-Eakin, Lovely, and Tosun (2004) showed that low values of this parameter (mainly $\psi<0.34$ ) produced immiserizing steady state growth results. It was argued earlier in Section B that the literature on returns to education pointed to relatively higher parameter estimates particularly for developing countries. Hence, such low $\psi$ values would not be anticipated in a two-region world with developed and developing countries. In a simulation with $\psi=0.4$, results did not change significantly to alter the main conclusions of the $^{\text {paper. }^{25}}$

\section{SUMMARY AND CONCLUSIONS}

This paper examines the economic effects of aging trends using the population projections for the developed and developing regions of the world. Unlike the majority of studies on aging, the paper addresses the political economy of aging and education spending through a median voter model. While there is a growing literature that examines the link between population aging and international capital mobility, population aging has not been

\footnotetext{
${ }^{24}$ Poutvaara (2004) recently addressed the political economy of both education and social security in an overlapping generations model. However, that study does not examine population aging.

${ }^{25}$ Results for this simulation are not reported in this paper but available from the author upon request.
} 
widely addressed in an open economy framework with international labor mobility. The paper fills this gap by modeling perfect international labor mobility.

It is argued that labor mobility has a dual effect on the economy. Besides the contribution of young migrant workers to the economy as laborers, these workers also contribute to capital accumulation as savers. This paper highlights another effect through migrant workers' involvement in the political process of fiscal policy. When allowed to vote, migrant workers change the political structure composed of young and elderly voters in both labor-receiving and labor-sending countries. In a majority voting mechanism for fiscal policy decisions, political shifts resulting from labor migration may have sizable effects on government programs such as education, and in turn may have strong growth and welfare effects.

For the analysis, a two-region, two-period overlapping generations model with international labor mobility and a politically responsive fiscal policy is used. The numerical simulations based on United Nations population projections for the developed and developing regions show significant labor movements from the developed to the developing region throughout the 2000-60 period. While labor inflows seem to help the developed region recover from the aging trend, this region incurs an overall decrease in income per worker and consumption. Nevertheless, a comparison with an alternative capital mobility model without labor mobility indeed shows the importance of migrant labor and their political participation. The developed region suffers from substantial income and consumption decreases under this capital mobility model, which is averted, to a large extent, in the labor mobility model. The developing region, on the other hand, seems to benefit more in the capital mobility model. However, this region experiences significant growth under both models. These comparisons show that the choice between labor and capital mobility indeed matters for the analysis of the effects of population aging.

Further comparisons are also made using alternative assumptions about labor mobility and the political process of fiscal policy. The full labor mobility model performed quite well particularly when it is compared to a scenario where labor migrates to the developed region but does not participate in the political system for the first thirty-year period. This scenario gives particularly inferior economic results for the developed region. Constraining political participation of young migrant workers does not seem to help when these young workers can vote for greater education spending that sets a growth process through human capital enhancement. 
Table 1. Education Spending and Migration in Developed and Developing Regions

\begin{tabular}{|c|c|c|c|c|}
\hline Region & $\begin{array}{c}\text { Percent Change in } \\
\text { Education Spending } \\
\text { Per Capita } \\
(1995-2000)\end{array}$ & $\begin{array}{c}\text { Average Annual } \\
\text { Education Spending } \\
\text { Per Capita } \\
\text { in US Dollars } \\
\text { (1995-2000) }\end{array}$ & $\begin{array}{l}\text { Migrant Stock } \\
\text { in } 2000 \text { (Percent of } \\
\text { Total Population) 1/ }\end{array}$ & $\begin{array}{c}\text { Net Migration } \\
\text { (Rate per } 1000 \\
\text { Population) } \\
(1995-2000) 2 /\end{array}$ \\
\hline $\begin{array}{l}\text { Average of } 23 \text { high income OECD } \\
\text { countries }\end{array}$ & 12.26 & 1,490 & 10.85 & 2.37 \\
\hline $\begin{array}{l}\text { Three high income OECD countries } \\
\text { with the highest net migration rate } 3 /\end{array}$ & 18.50 & 1,367 & 23.30 & 6.44 \\
\hline $\begin{array}{l}\text { Three high income OECD countries } \\
\text { with the lowest net migration rate } 4 /\end{array}$ & 10.00 & 1,832 & 10.66 & 0.40 \\
\hline Less developed regions (UN definition) & 9.09 & 122 & 5.27 & -0.67 \\
\hline $\begin{array}{l}\text { Least advanced economies (UN } \\
\text { definition) }\end{array}$ & -0.40 & 7 & 1.60 & -0.48 \\
\hline
\end{tabular}

Sources: International migration data is from United Nations Population Division, Department of Economic and Social Affairs, International Migration, 2002 (United Nations, 2002b). Education spending data is from World Development Indicators, World Bank, 2003 CD-ROM (World Bank, 2003).

1/ Migrant stock: For most countries, the mid-year estimate of the number of people who are born outside the country. For countries lacking data on place of birth, the estimated number of noncitizens. In both cases, migrant stock also includes refugees, some of whom may not be foreign-born.

2/ Net migration rate: The net number of migrants (annual number of immigrants less the annual number of emigrants, including both citizens and noncitizens), divided by the average population of the receiving country. It is expressed as the net number of migrants per 1,000 population.

3/ These are Luxembourg (9.4), Australia (5.1), and Ireland (4.9).

4/ These are Iceland (0.2), Japan (0.4), and Switzerland (0.6). 
Table 2. Comparisons with Alternative Factor Mobility Models 1/

\begin{tabular}{|c|c|c|c|c|c|}
\hline & \multirow[b]{2}{*}{ Time Periods } & \multicolumn{2}{|c|}{$\begin{array}{l}\begin{array}{l}\text { Labor Mobility Model } \\
\text { (No Capital Mobility) }\end{array} \\
\end{array}$} & \multicolumn{2}{|c|}{$\begin{array}{l}\text { Capital Mobility Model } \\
\text { (No Labor Mobility) }\end{array}$} \\
\hline & & $\begin{array}{l}\text { Developed } \\
\text { Region } \\
\text { (1) }\end{array}$ & $\begin{array}{l}\text { Developing } \\
\text { Region } \\
\text { (2) }\end{array}$ & $\begin{array}{l}\text { Developed } \\
\text { Region } \\
\text { (3) }\end{array}$ & $\begin{array}{c}\text { Developing } \\
\text { Region } \\
\text { (4) }\end{array}$ \\
\hline \multirow[t]{3}{*}{ Number of workers } & $2000-2030$ & 41.1 & 39.8 & 22.2 & 51.3 \\
\hline & 2030-2060 & 30.9 & 34.4 & 12.0 & 46.0 \\
\hline & $2000-2060$ & 84.7 & 87.8 & 36.9 & 121.0 \\
\hline \multirow[t]{3}{*}{ Capital stock per worker } & $2000-2030$ & -10.0 & 48.7 & -35.5 & 80.5 \\
\hline & $2030-2060$ & 4.2 & 23.7 & -6.7 & 16.1 \\
\hline & $2000-2060$ & -6.2 & 84.0 & -39.8 & 109.5 \\
\hline \multirow[t]{3}{*}{ Human capital per worker } & $2000-2030$ & 7.8 & -1.2 & -18.2 & 11.2 \\
\hline & 2030-2060 & -6.3 & 3.8 & -24.5 & 3.2 \\
\hline & $2000-2060$ & 1.0 & 2.6 & -38.2 & 14.8 \\
\hline \multirow[t]{3}{*}{ Income per worker } & 2000-2030 & 1.6 & 13.1 & -24.3 & 30.5 \\
\hline & 2030-2060 & -2.9 & 10.0 & -19.0 & 7.3 \\
\hline & $2000-2060$ & -1.4 & 24.4 & -38.7 & 40.0 \\
\hline \multirow[t]{3}{*}{ Education tax rate } & $2000-2030$ & 18.5 & -14.1 & -19.0 & -1.4 \\
\hline & $2030-2060$ & -11.8 & -0.4 & -44.4 & 0.4 \\
\hline & $2000-2060$ & 4.5 & -14.5 & -55.0 & -1.1 \\
\hline \multirow[t]{3}{*}{$\begin{array}{l}\text { Education spending per } \\
\text { worker }\end{array}$} & $2000-2030$ & 20.3 & -2.8 & -38.8 & 28.6 \\
\hline & 2030-2060 & -14.7 & 9.6 & -54.8 & 7.7 \\
\hline & $2000-2060$ & 2.6 & 6.5 & -72.3 & 38.5 \\
\hline \multirow[t]{3}{*}{ Consumption of young } & 2000-2030 & -3.2 & 18.9 & -23.2 & 31.3 \\
\hline & 2030-2060 & -0.5 & 10.2 & -13.8 & 7.2 \\
\hline & 2000-2060 & -3.7 & 31.1 & -33.7 & 40.8 \\
\hline \multirow[t]{3}{*}{ Consumption of old } & $2000-2030$ & 5.4 & -16.3 & 14.0 & -22.2 \\
\hline & $2030-2060$ & -6.5 & 8.9 & 27.6 & 23.7 \\
\hline & 2000-2060 & -1.4 & -8.9 & -17.5 & -3.7 \\
\hline \multirow[t]{3}{*}{$\begin{array}{l}\text { Sum of young and old } \\
\text { consumption }\end{array}$} & $2000-2030$ & 1.4 & -3.0 & -3.5 & -2.0 \\
\hline & $2030-2060$ & -3.8 & 9.5 & -22.4 & 15.4 \\
\hline & $2000-2060$ & -2.5 & 6.2 & -25.1 & 13.1 \\
\hline
\end{tabular}


Table 2. Comparisons with Alternative Factor Mobility Models 1/ (concluded)

\begin{tabular}{|c|c|c|c|c|c|c|c|}
\hline & \multirow[b]{2}{*}{ Time Periods } & \multicolumn{2}{|c|}{$\begin{array}{c}\text { Labor Mobility Model } \\
\text { with Mobility } \\
\text { After } 2030 \\
\text { (No Capital Mobility) }\end{array}$} & \multicolumn{2}{|c|}{$\begin{array}{c}\text { Labor Mobility Model } \\
\text { with Migrants Voting } \\
\text { After } 2030 \\
\text { (No Capital Mobility) }\end{array}$} & \multicolumn{2}{|c|}{$\begin{array}{l}\text { Labor Mobility Model } \\
\text { with Fixed Education } \\
\text { Spending per Worker } \\
\text { (No Capital Mobility) }\end{array}$} \\
\hline & & $\begin{array}{l}\text { Developed } \\
\text { Region } \\
\text { (5) }\end{array}$ & $\begin{array}{l}\text { Developing } \\
\text { Region } \\
(6)\end{array}$ & $\begin{array}{l}\text { Developed } \\
\text { Region } \\
\text { (7) }\end{array}$ & $\begin{array}{l}\text { Developing } \\
\text { Region } \\
\text { (8) }\end{array}$ & $\begin{array}{l}\text { Developed } \\
\text { Region } \\
\text { (9) }\end{array}$ & $\begin{array}{l}\text { Developing } \\
\text { Region } \\
\text { (10) }\end{array}$ \\
\hline \multirow[t]{3}{*}{ Number of workers } & 2000-2030 & 22.2 & 51.3 & 76.2 & 18.3 & 53.7 & 32.1 \\
\hline & 2030-2060 & 32.9 & 35.7 & 27.2 & 32.3 & 20.9 & 39.7 \\
\hline & $2000-2060$ & 62.4 & 105.4 & 124.1 & 56.5 & 85.8 & 84.5 \\
\hline \multirow[t]{3}{*}{ Capital stock per worker } & $2000-2030$ & 3.9 & 37.4 & -27.9 & 75.7 & -17.4 & 57.5 \\
\hline & 2030-2060 & -9.5 & 28.4 & -11.7 & 4.6 & 15.8 & 15.4 \\
\hline & $2000-2060$ & 06.0 & 76.4 & -36.4 & 83.9 & -4.3 & 81.7 \\
\hline \multirow[t]{3}{*}{ Human capital per worker } & 2000-2030 & -8.4 & $0-.9$ & -47.2 & -27.7 & 0.0 & 0.0 \\
\hline & 2030-2060 & 12.6 & 1.2 & 40.6 & 39.9 & 0.0 & 0.0 \\
\hline & 2000-2060 & 3.1 & 2.1 & -25.8 & 1.1 & 0.0 & 0.0 \\
\hline \multirow[t]{3}{*}{ Income per worker } & $2000-2030$ & -4.5 & 11.7 & -41.5 & -3.1 & -6.1 & 16.2 \\
\hline & $2030-2060$ & 4.7 & 9.5 & 20.6 & 27.1 & 5.0 & 4.8 \\
\hline & 2000-2060 & 0.0 & 22.3 & -29.5 & 23.2 & -1.4 & 21.8 \\
\hline \multirow[t]{3}{*}{ Education tax rate } & $2000-2030$ & -16.3 & -8.6 & -81.5 & -56.5 & 6.7 & -13.8 \\
\hline & $2030-2060$ & 29.5 & -6.1 & 236.4 & 91.5 & 1.7 & -17.8 \\
\hline & 2000-2060 & 8.4 & -14.1 & -37.6 & -16.7 & 1.7 & -17.8 \\
\hline \multirow[t]{3}{*}{$\begin{array}{l}\text { Education spending per } \\
\text { worker }\end{array}$} & 2000-2030 & -20.2 & 2.1 & -89.3 & -57.9 & 0.0 & 0.0 \\
\hline & 2030-2060 & 35.3 & 2.9 & 310.9 & 144.0 & 0.0 & 0.0 \\
\hline & $2000-2060$ & 8.0 & 5.1 & -56.2 & 2.7 & 0.0 & 0.0 \\
\hline \multirow[t]{3}{*}{ Consumption of young } & $2000-2030$ & -1.6 & 15.1 & -36.3 & 17.0 & -8.9 & 22.1 \\
\hline & 2030-2060 & -1.5 & 11.7 & 12.3 & 11.8 & 6.3 & 6.3 \\
\hline & 2000-2060 & -3.0 & 28.6 & -28.4 & 30.8 & -3.1 & 29.9 \\
\hline \multirow[t]{3}{*}{ Consumption of old } & 2000-2030 & -3.9 & -13.2 & -8.4 & -27.2 & 7.4 & -18.2 \\
\hline & 2030-2060 & 4.7 & 3.4 & -24.1 & 22.9 & -14.4 & 14.7 \\
\hline & 2000-2060 & 0.6 & -10.2 & -30.5 & -10.5 & -8.1 & -6.2 \\
\hline \multirow[t]{3}{*}{$\begin{array}{l}\text { Sum of young and old } \\
\text { consumption }\end{array}$} & 2000-2030 & -2.8 & -2.5 & -21.5 & -10.5 & -0.3 & -3.0 \\
\hline & $2030-2060$ & 1.8 & 7.1 & -10.2 & 17.4 & -5.5 & 10.7 \\
\hline & $2000-2060$ & -1.1 & 4.5 & -29.5 & 5.1 & -5.8 & 7.4 \\
\hline
\end{tabular}

Source: Computed by author.

1/ All numbers refer to percentage changes between the years indicated in the time period. 
Table 3. Comparison of Predicted and Actual Labor Flows to Developed Region

\begin{tabular}{|c|c|c|}
\hline & $2000-2030$ & $2030-2060$ \\
\hline Predicted average annual number of labor migrants to developed region. & $3,256,141$ & $4,580,496$ \\
\hline $\begin{array}{l}\text { Ratio of predicted average annual number of labor migrants to actual foreign } \\
\text { population inflows in } 2000 \text { (in percent). }\end{array}$ & 98.0 & 138.0 \\
\hline $\begin{array}{l}\text { Ratio of predicted average annual number of labor migrants to actual foreign } \\
\text { worker inflows in } 2000 \text { (in percent). }\end{array}$ & 190.0 & 267.0 \\
\hline
\end{tabular}


Figure 1.

Population Growth Rates in Developed and Developing Regions

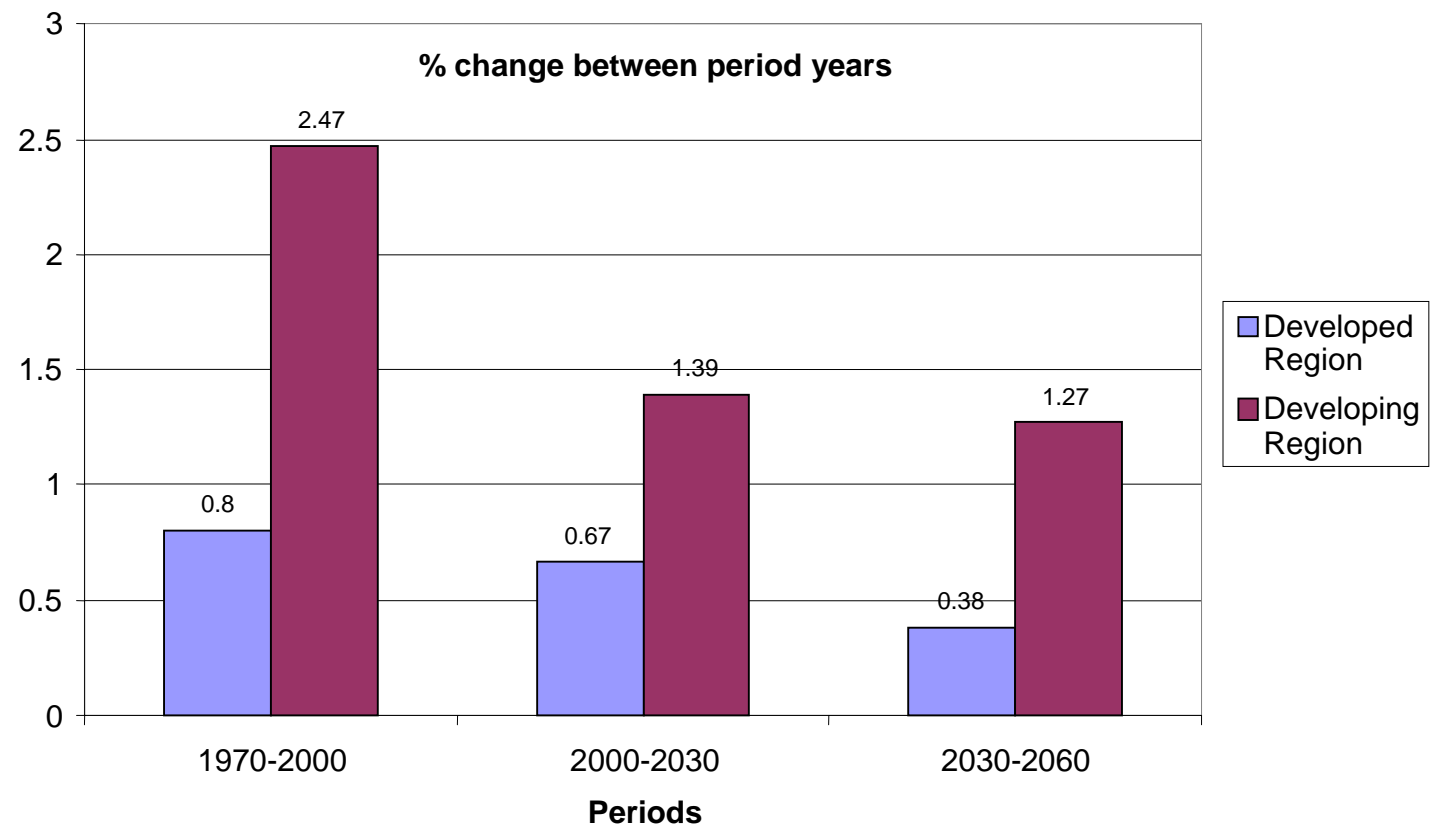

Figure 2.

Composition of the Change in the Number of Workers in the Developed

Region

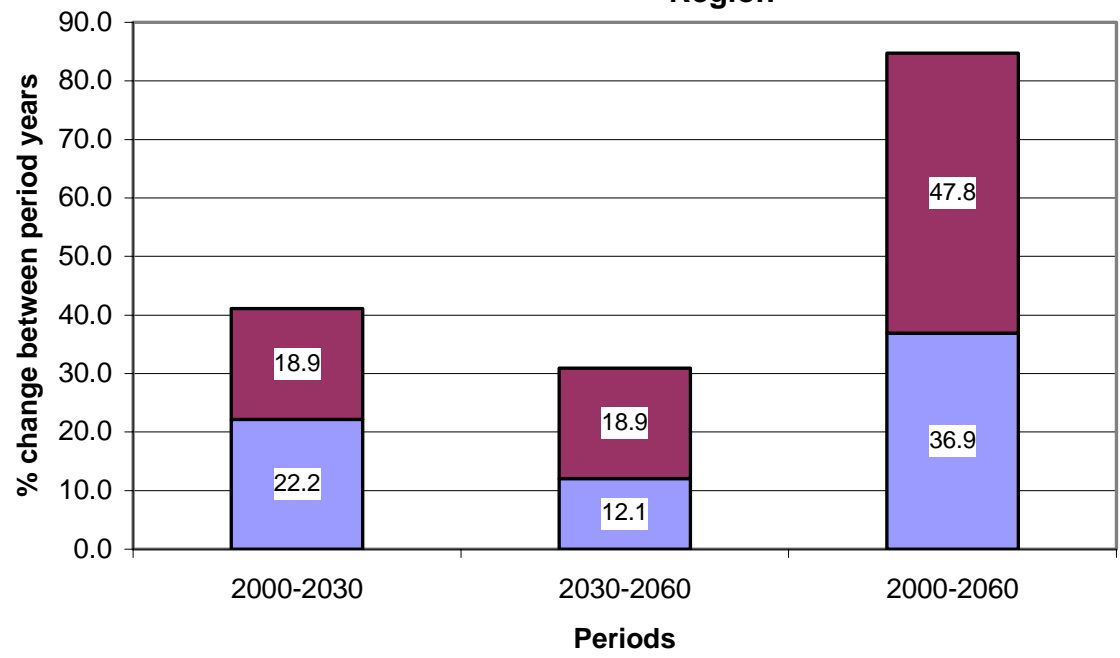

\% Change Due to Immigration

$\square \%$ Change Due to Own Growth 
Figure 3.

Ratio of Immigrant Labor to Developed Region Population

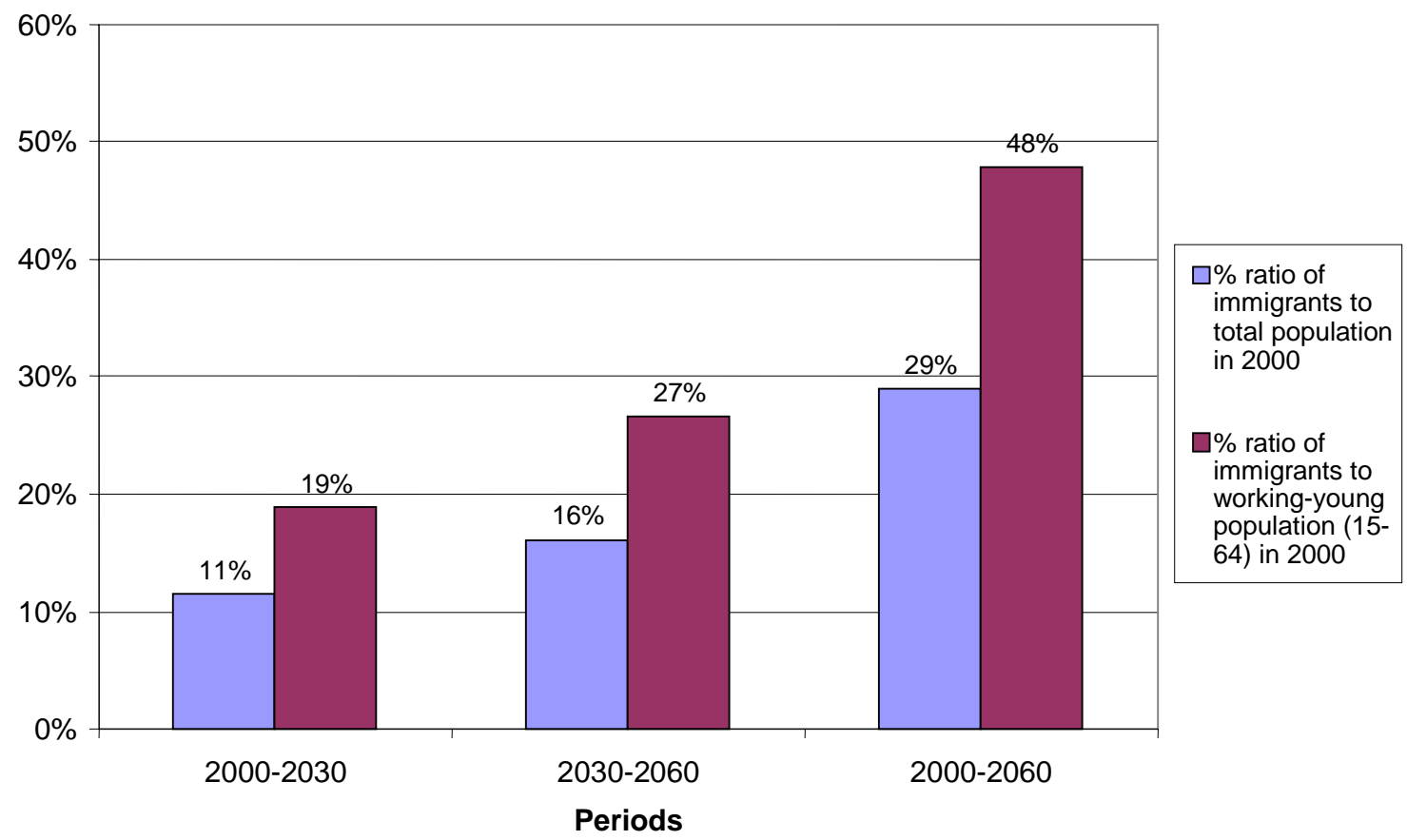

Figure 4.

Composition of the Change in the Number of Workers in the Developing

Region

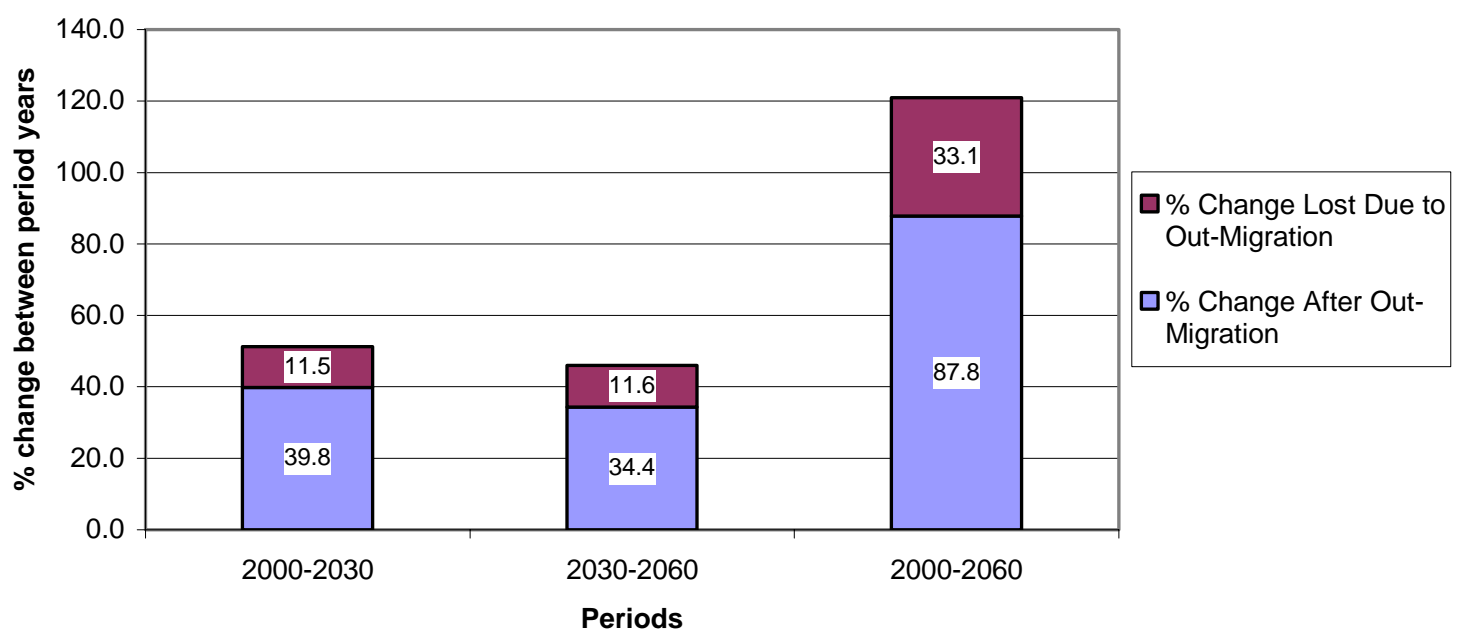


Figure 5.

Change in Capital Stock Per Worker in Developed and Developing Regions

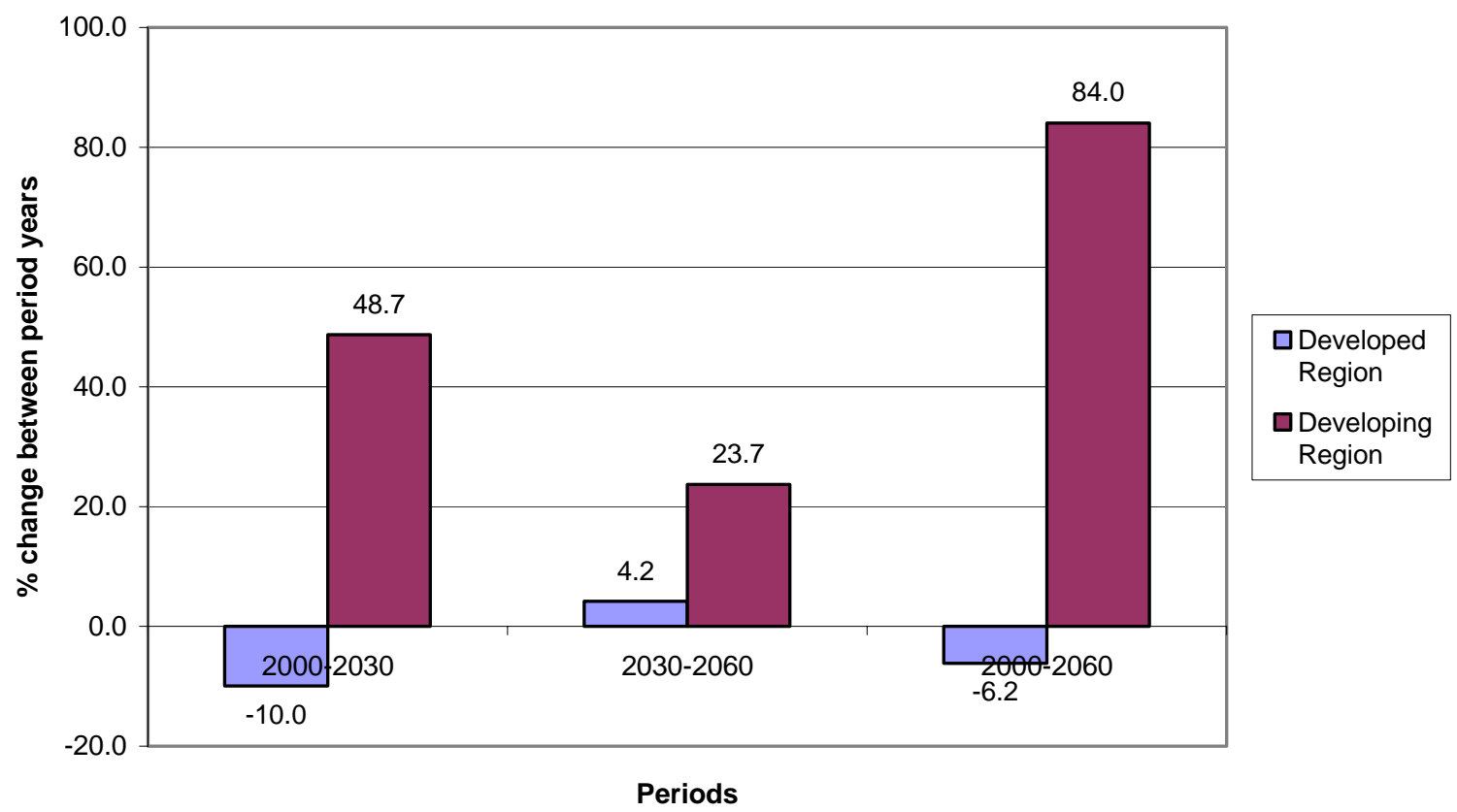

Figure 6.

Change in Human Capital Per Worker in Developed and Developing Regions

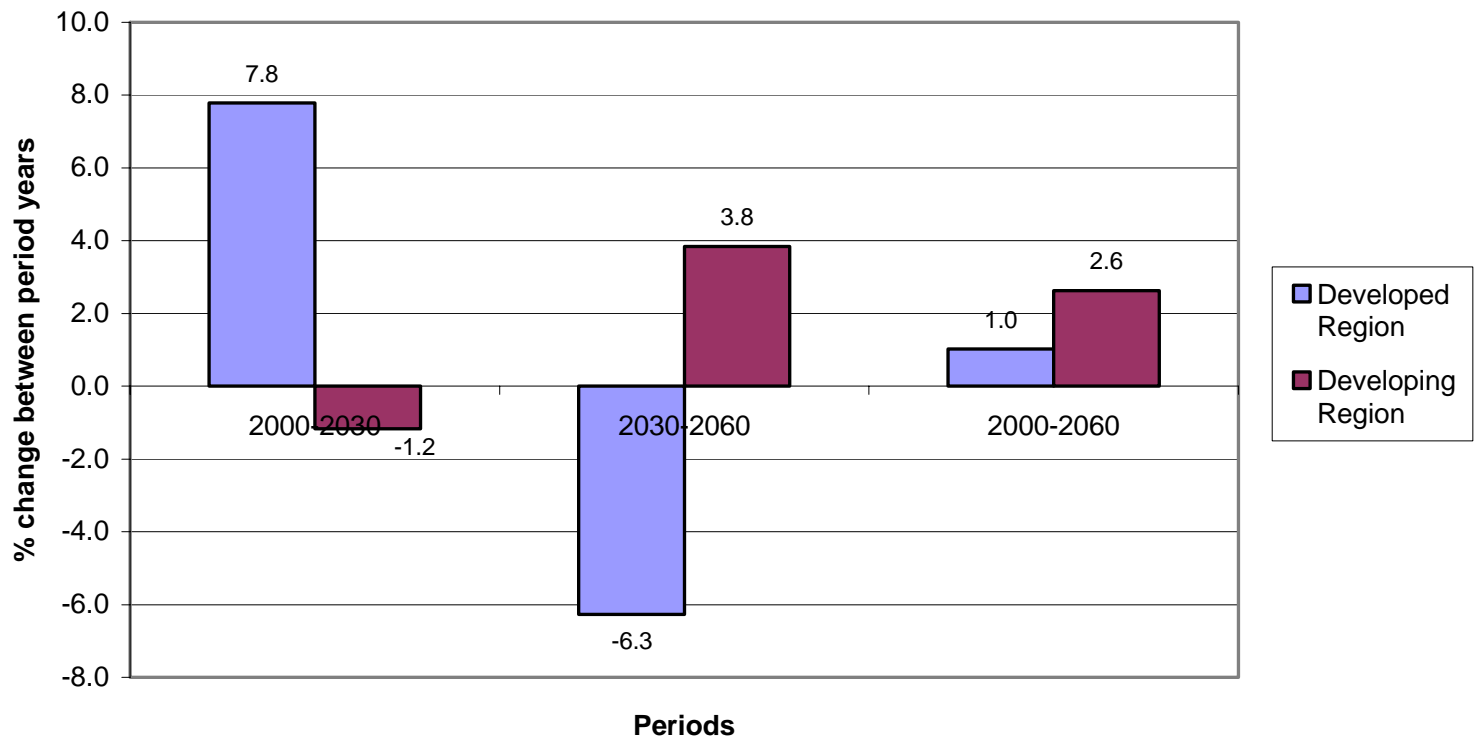


Figure 7.

Change in Education Tax Rate in Developed and Developing Regions

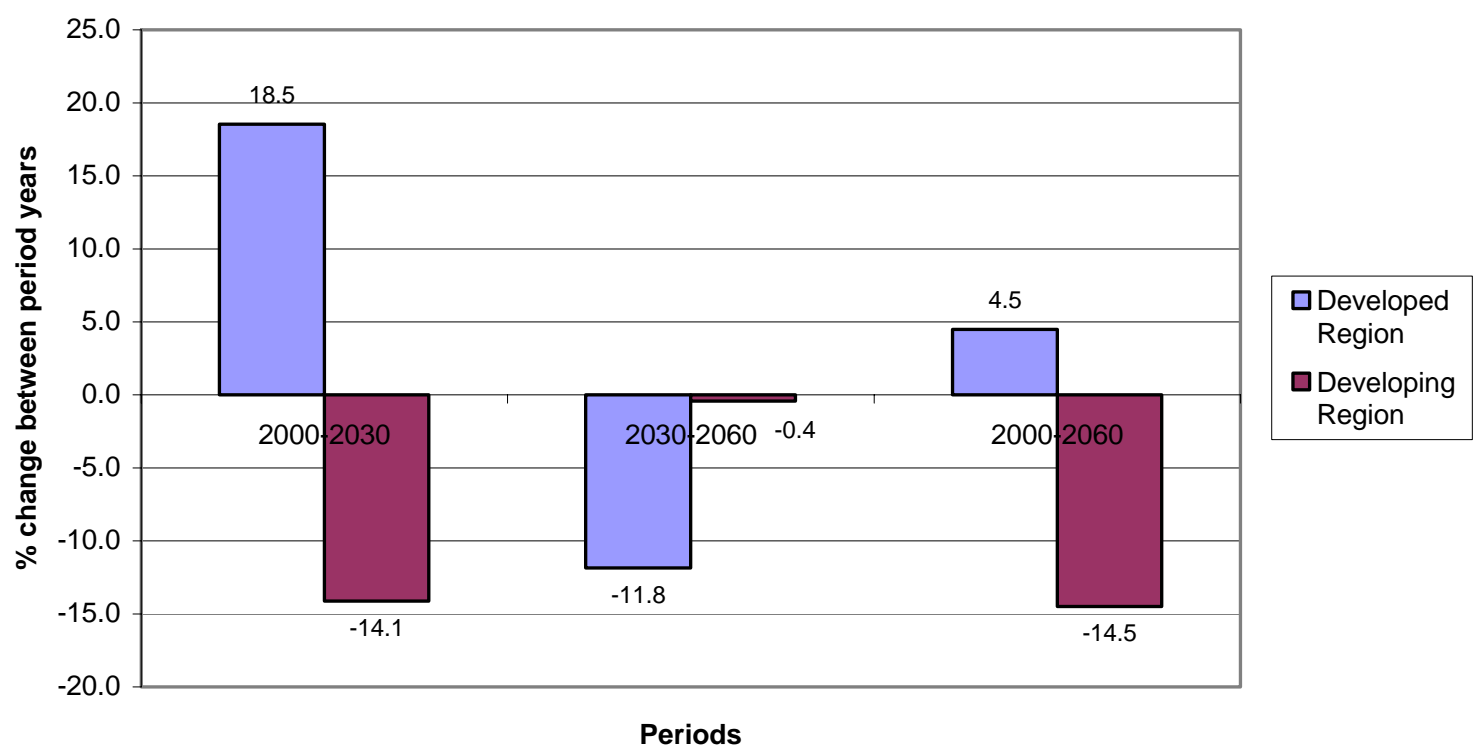

Figure 8.

Change in Education Spending Per Worker in Developed and Developing Regions

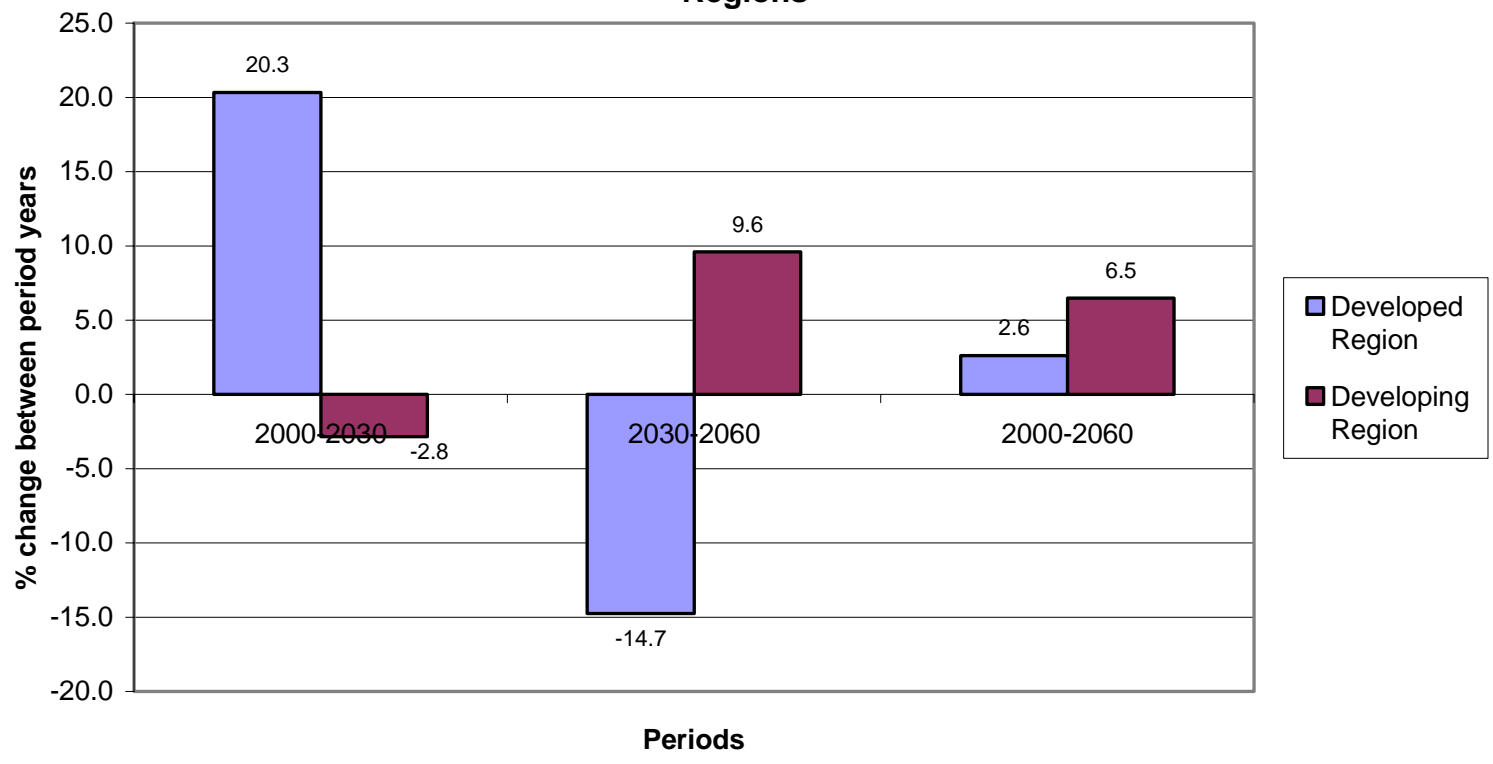


Figure 9.

Change in Income Per Worker in Developed and Developing Regions

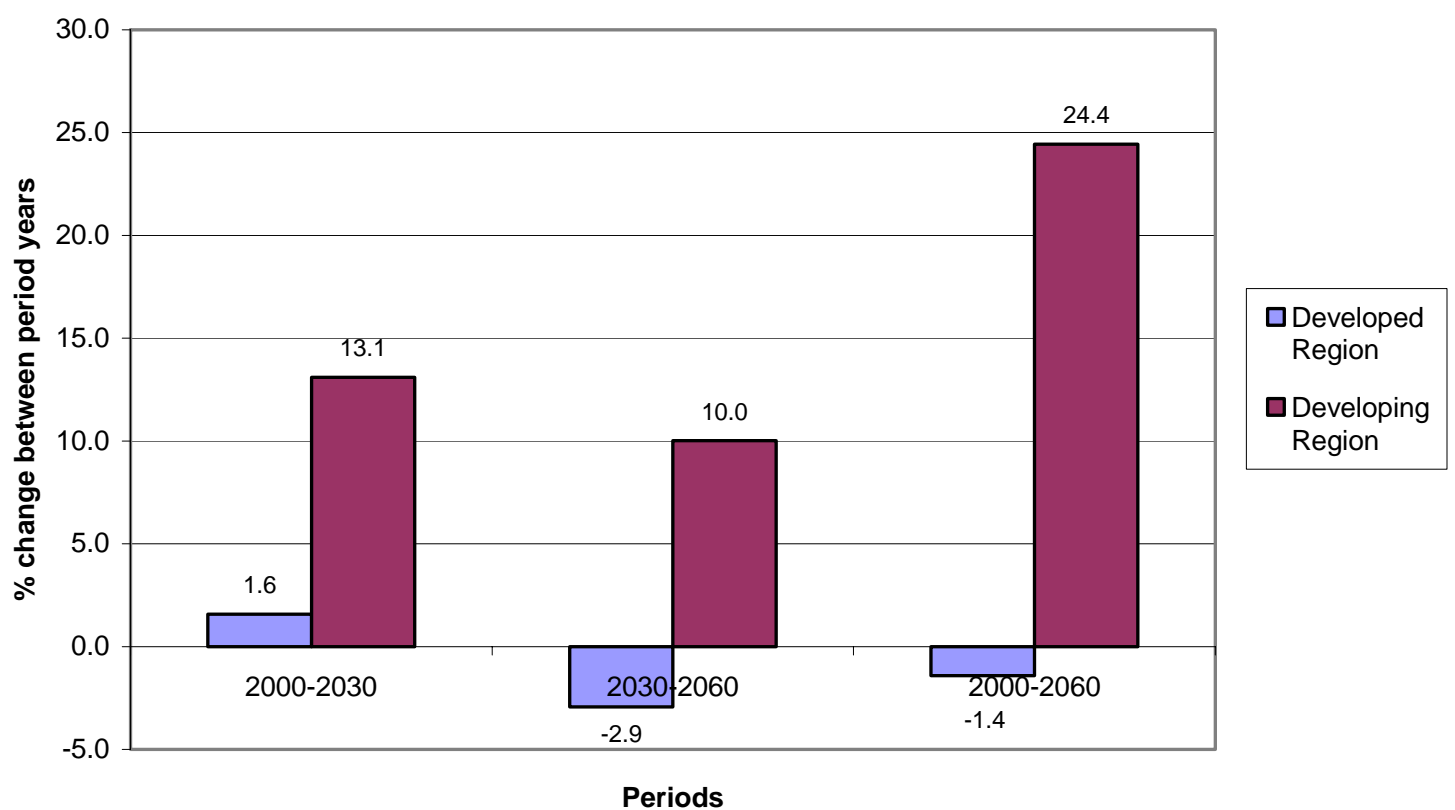

Figure 10.

Change in Consumption of Young in Developed and Developing Regions

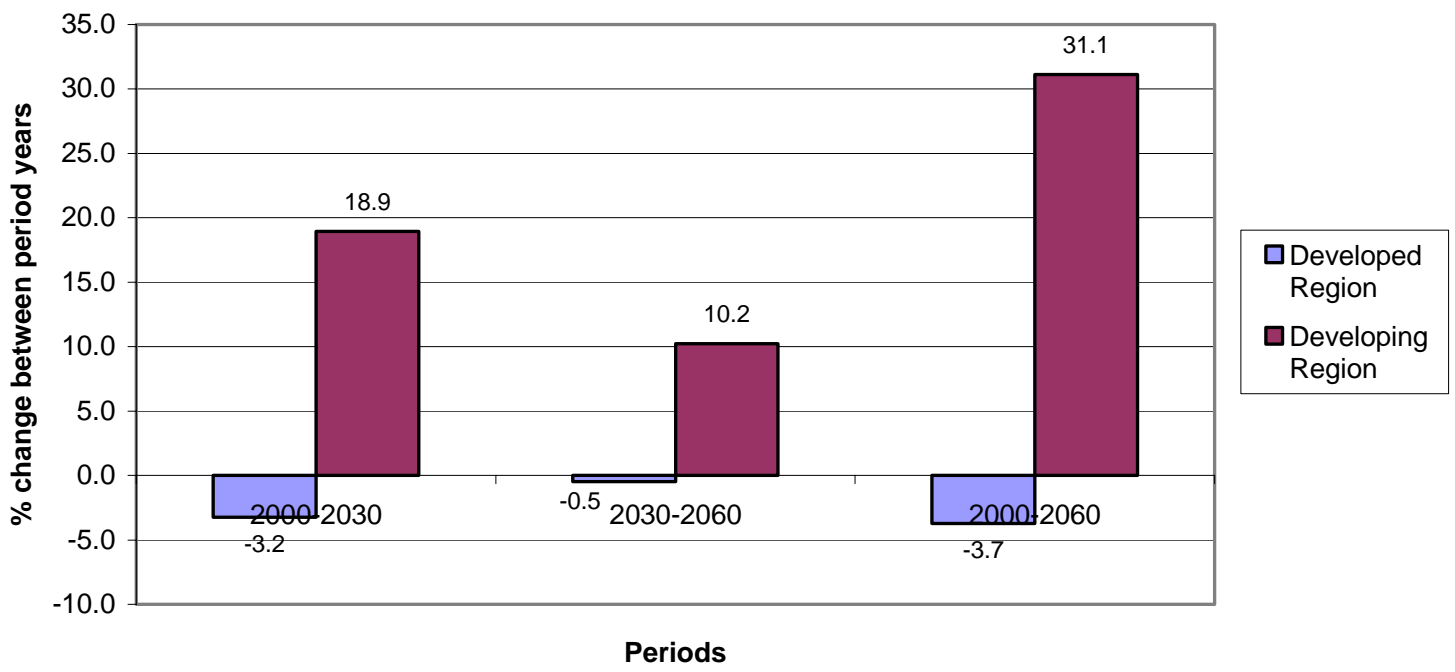


Figure 11.

Change in Consumption of Old in Developed and Developing Regions

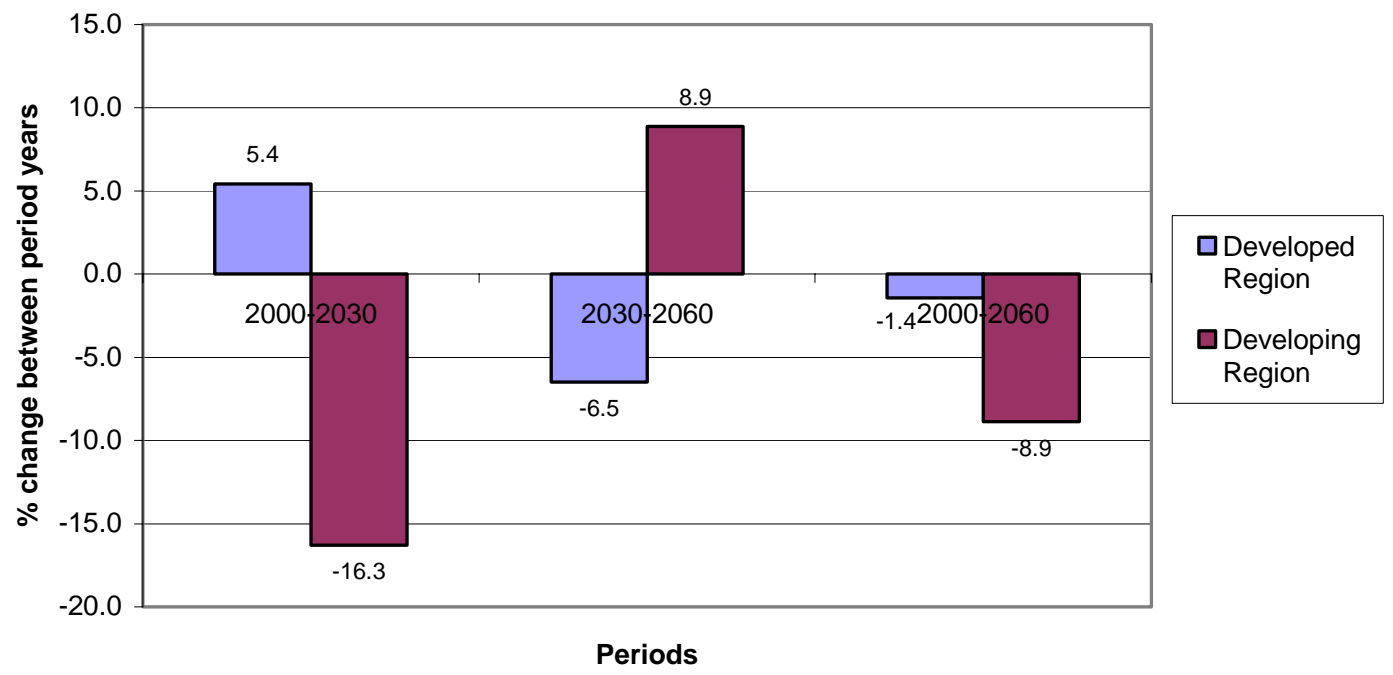

Figure 12.

Change in Sum of Young and Old Consumption in Developed and Developing Regions

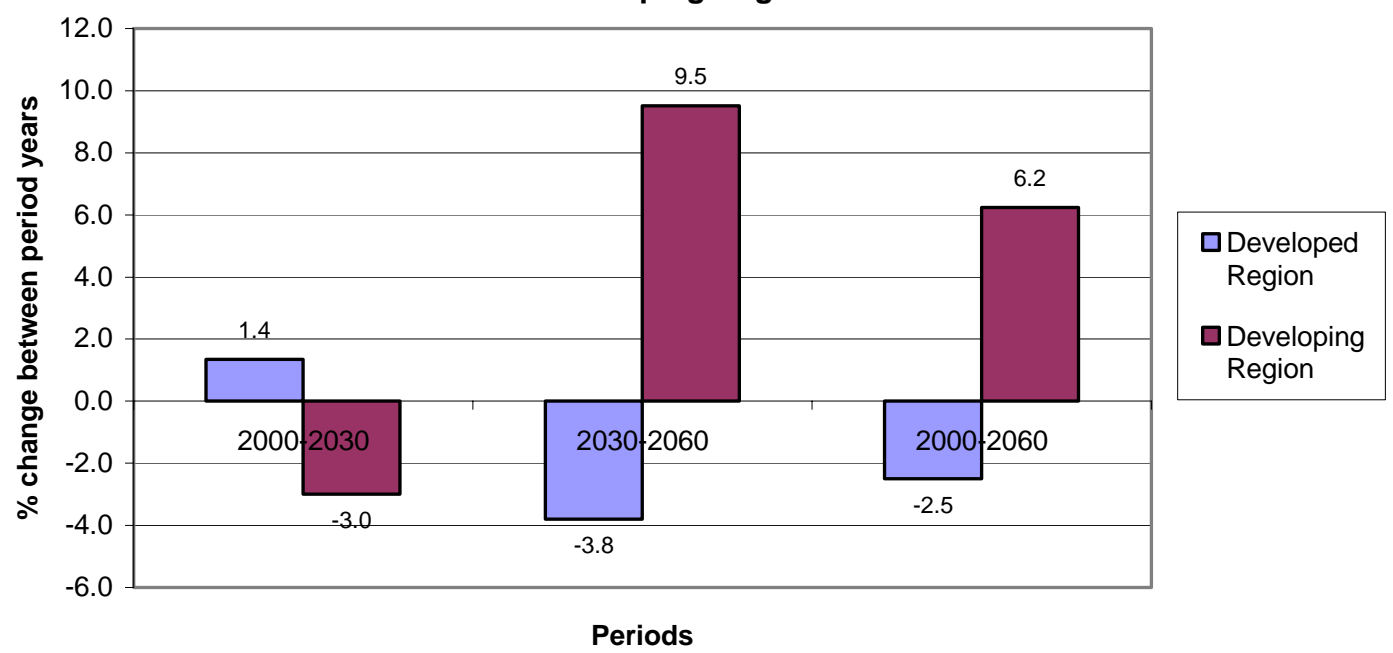




\section{APPENDIX: THE EFFECT OF INCREASING DEPENDENCY RATIO ON THE ABILITy LEVEL OF THE MEDiAN VOTER}

Recall that median voter is defined by $N_{t-1}+N_{t} \int_{0}^{a_{m}} f(a) d a=\frac{N_{t-1}+N_{t}}{2}$. Rewriting this: $N_{t-1}+N_{t} F\left(a_{m}\right)-N_{t} F(0)=\frac{N_{t-1}+N_{t}}{2}$, which can be rearranged as: $F\left(a_{m}\right)-F(0)=\frac{N_{t}-N_{t-1}}{2 N_{t}}$. Differentiating both sides we get, $F^{\prime}\left(a_{m}\right) d a_{m}=\frac{\hat{N}_{t}-\hat{N}_{t-1}}{2\left(1+\eta^{*}\right)}$, where $\hat{N}_{t}=\frac{d N_{t}}{N_{t}}, \hat{N}_{t-1}=\frac{d N_{t-1}}{N_{t-1}}$, and $1+\eta^{*}=\frac{N_{t}}{N_{t-1}}$ evaluated at the initial steady state. Finally this can be rearranged as $d a_{m}=\frac{\hat{N}_{t}-\hat{N}_{t-1}}{F^{\prime}\left(a_{m}\right) 2(1+\eta)}$ which is negative when $\hat{N}_{t}<\hat{N}_{t-1}$. 
Appendix Table 1: List of Economies Used in Population Projections

\begin{tabular}{|c|c|c|c|}
\hline \multirow{2}{*}{$\begin{array}{l}\text { Advanced economies } \\
\text { Australia }\end{array}$} & \multicolumn{3}{|c|}{ Developing Economies } \\
\hline & Afghanistan, Islamic Rep. of & Gambia, The & Panama \\
\hline Austria & Albania & Ghana & Papua New Guinea \\
\hline Belgium & Algeria & Guatemala & Paraguay \\
\hline Canada & Angola & Guinea & Peru \\
\hline Cyprus & Azerbaijan & Guyana & Philippines \\
\hline Denmark & Argentina & Haiti & Poland \\
\hline Finland & Bahamas, The & Honduras & Guinea-Bissau \\
\hline France & Bahrain & Hungary & Qatar \\
\hline Germany & Bangladesh & India & Romania \\
\hline Greece & Armenia & Indonesia & Russian Federation \\
\hline Hong Kong SAR & Barbados & Iran, Islamic Rep. of & Rwanda \\
\hline Iceland & Bhutan & Iraq & Saint Lucia \\
\hline Ireland & Bolivia & Côte d'Ivoire & Saint Vincent and the Granadines \\
\hline Israel & Botswana & Jamaica & São Tomé and Príncipe \\
\hline Italy & Brazil & Kazakhstan & Saudi Arabia \\
\hline Japan & Belize & Jordan & Senegal \\
\hline Republic of Korea & Solomon Islands & Kenya & Sierra Leone \\
\hline Luxembourg & Bulgaria & Kuwait & Slovak Republic \\
\hline Netherlands & Myanmar & Kyrgyzstan & Viet Nam \\
\hline New Zealand & Burundi & Lao People's Dem. Rep. & Slovenia \\
\hline Norway & Belarus & Lebanon & Somalia \\
\hline Portugal & Cambodia & Lesotho & South Africa \\
\hline Singapore & Cameroon & Latvia & Zimbabwe \\
\hline Spain & Cape Verde & Libyan Arab Jamahiriya & Sudan \\
\hline Sweden & Central African Rep. & Lithuania & Suriname \\
\hline Switzerland & Sri Lanka & Madagascar & Swaziland \\
\hline United Kingdom & Chad & Malawi & Syrian Arab Republic \\
\hline \multirow[t]{20}{*}{ United States } & Chile & Malaysia & Tajikistan \\
\hline & China & Maldives & Thailand \\
\hline & Colombia & Mali & Togo \\
\hline & Comoros & Malta & Tonga \\
\hline & Congo, Rep. of & Mauritania & Trinidad and Tobago \\
\hline & Congo, Dem. Rep. of & Mauritius & United Arab Emirates \\
\hline & Costa Rica & Mexico & Tunisia \\
\hline & Croatia & Mongolia & Turkey \\
\hline & Czech Republic & Moldova & Turkmenistan \\
\hline & Benin & Morocco & Uganda \\
\hline & Dominican Republic & Mozambique & Ukraine \\
\hline & Ecuador & Oman & Egypt \\
\hline & El Salvador & Namibia & Tanzania \\
\hline & Equatorial Guinea & Nepal & Burkina Faso \\
\hline & Ethiopia & Netherlands Antilles & Uruguay \\
\hline & Estonia & Vanuatu & Uzbekistan \\
\hline & Fiji & Nicaragua & Venezuela \\
\hline & Djibouti & Niger & Samoa \\
\hline & Gabon & Nigeria & Yemen \\
\hline & Georgia & Pakistan & Zambia \\
\hline
\end{tabular}

Source: United Nations (2002a). 


\section{References}

Allais, Maurice, 1947, Economie et Intérêt (Paris: Imprimerie Nationale).

American Association of Retired Persons (AARP), 2004, "Political Behavior and Values Across the Generations: A Summary of Selected Findings.” AARP Strategic Issues Research, July. Also available via the Internet at: http://www.aarp.org/research/reference/publicopinions/aresearch-import-886.html.

Bearse, Peter, Gerhard Glomm, and B. Ravikumar, 2000, "On the Political Economy of Means-Tested Education Vouchers,” European Economic Review, Vol. 44, pp. 90415.

Black, Duncan, 1948, “On the Rationale of Group Decision-Making,” Journal of Political Economy, Vol. 56, pp. 23-34.

Börsch-Supan, Axel, 1996, “The Impact of Population Aging on Savings, Investment and Growth in the OECD Area.” In Future Global Capital Shortages: Real Threat or Pure Fiction? Pp. 103-41 (Paris: Organisation for Economic Co-operation and Development).

Buiter, Willena Hendrik, 1981, "Time Preference and International Lending and Borrowing in an Overlapping Generations Model,” Journal of Political Economy, Vol. 89, No. 4, pp. 769-97.

Button, James W., 1992, “A Sign of Generational Conflict: The Impact of Florida’s Aging Voters on Local School and Tax Referenda,” Social Science Quarterly, Vol. 73, No. 4, pp. 786-97.

Caldwell, Steven, and others, 1999, “Social Security's Treatment of Postwar Americans," in L.H. Summers (ed.), Tax Policy and the Economy, Vol. 13 (Cambridge, Massachusetts: MIT Press).

Center for Strategic and International Studies. 2002. "Meeting the Challenge of Global Aging: A Report to World Leaders from the CSIS Commission on Global Aging," CSIS Panel Report ( March) (Washington: The CSIS Press).

Coronado, Julia Lynn, Don Fullerton, and Thomas Glass, 2000, “The Progressivity of Social Security,” NBER Working Paper No. 7250 (Cambridge, Massachusetts: National Bureau of Economic Research).

Crettez, Bertrand, Philippe Michel, and Jean-Pierre Vidal, 1996, “Time Preference and Labor Migration in an OLG Model with Land and Capital,” Journal of Population Economics, Vol. 9, pp. 387-403. 
— of Population Economics, Vol. 11, pp. 149-58.

Cutler, David, James Poterba, Louise Sheiner, and Lawrence Summers, 1990, “An Aging Society: Opportunity or Challenge,” Brookings Papers on Economic Activity, Vol. 1, pp. 1-73.

Deller, Steven C., and Norman Walzer, 1993, “The Effects of an Aging Rural Population on the Financing of Rural Public Education,” Journal of Research in Rural Education, Vol. 9, No. 2, pp. 104-14.

Diamond, Peter A., 1965, “National Debt in a Neoclassical Growth Model,” American Economic Review, Vol. 55, pp. 1126-50.

Elmendorf, D.W., and L.M. Sheiner, 2000, "Should America Save for its Old Age? Fiscal Policy, Population Aging, and National Saving,” Journal of Economic Perspectives, Vol. 14, No. 3, pp. 57-74.

Galor, Oded, 1986, “Time Preference and International Labor Migration,” Journal of Economic Theory, Vol. 38, pp. 1-20.

— 1992, “The Choice of Factor Mobility in a Dynamic World,” Journal of Population Economics, Vol. 5, pp. 135-44.

Gradstein, Mark, and Michael Kaganovich, 2004, “Aging Population and Education Finance,” Journal of Public Economics, Vol. 88, No. 12, pp. 2469-85.

Harris, Amy R., William N. Evans, and Robert M. Schwab, 2001, “Education Spending in an Aging America,” Journal of Public Economics, Vol. 81, No. 3, pp. 449-72.

Heller, Peter S., 2003, Who Will Pay? Coping with Aging Societies, Climate Change, and Other Long-Term Fiscal Challenges, (Washington: International Monetary Fund).

Holtz-Eakin, Douglas, Mary E. Lovely, and Mehmet S. Tosun, 2004, “Generational Conflict, Fiscal Policy, and Economic Growth,” Journal of Macroeconomics, Vol. 26, No. 1, pp. 1-23.

International Monetary Fund, 2003, Government Finance Statistics CD-ROM (Washington).

Jelassi, Mohamed Mehdi, and Serdar Sayan, 2004, "Population Growth Differentials and the Long-Run Trade Equilibrium,” (unpublished manuscript).

Kenc, Turalay, and Serdar Sayan, 2001, "Demographic Shock Transmission from Large to Small Countries: An Overlapping Generations CGE Analysis,” Journal of Policy Modeling Vol. 23, No. 6, pp. 677-702. 
Laitner, John, 2000a, "Simulating the Effect on Inequality and Wealth Accumulation of Eliminating the Federal Gift and Estate Tax," (unpublished: Department of Economics, Ann Arbor, MI: University of Michigan).

— 2000b, "Earnings within Education Groups and Overall Productivity Growth," Journal of Political Economy, Vol. 108, No. 4, pp. 807-32.

Leers, Theo, Lex C. Meijdam, and Harrie A.A. Verbon, 2004, “Ageing, Migration and Endogenous Public Pensions,” Journal of Public Economics, Vol. 88, No. 1-2, pp. 131-59.

National Research Council, 2000, Beyond Six Billion: Forecasting the World's Population, (Washington: National Academy Press).

OECD, 2002, Trends in International Migration, 2002 Edition. Available via the Internet at http://www.oecd.org/document/36/0,2340,en_2825_494553_2515108_1_1_1_1,00.ht $\underline{\mathrm{ml}}$

Psacharopoulos, George, 1985, "Returns to Education: A Further International Update and Implications,” Journal of Human Resources, Vol. 20, No. 4, pp. 583-604.

Poterba, James M., 1997, "Demographic Structure and the Political Economy of Public Education,” Journal of Public Policy and Management, Vol. 16, pp. 48-66.

Poutvaara, Panu, 2004, "On the Political Economy of Social Security and Public Education,” CESifo Working Paper No.424 (Munich, Germany: Center for Economic Studies and Ifo Institute for Economic Research).

Razin, Assaf, Efrain Sadka, and Philip Swagel, 2002, “The Aging Population and the Size of the Welfare State,” Journal of Political Economy, Vol. 110, No. 4, pp. 900-18.

Samuelson, Paul A., 1958, “An Exact Consumption-Loan Model of Interest with or without the Social Contrivance of Money,” Journal of Political Economy, Vol. 66, pp. 46782.

Storesletten, Kjetil, 2000, “Sustaining Fiscal Policy Through Immigration,” Journal of Political Economy, Vol. 108, No. 2, pp. 300-23.

Tosun, Mehmet S., 2001, “International Spillover Effects of a Demographic Shock When Fiscal Policy is Politically Responsive,” in Policy Evaluation with Computable General Equilibrium Models, Amedeo Fossati and Wolfgang Wiegard eds., Routledge.

— 2003, "Population Aging and Economic Growth: Political Economy and Open Economy Effects,” Economics Letters, Vol. 81, No. 3, pp. 291-96. 
United Nations, 2002a, World Population Prospects: The 2002 Revision, Department of Economic and Social Affairs, Population Division (New York: United Nations).

—_, 2002b, International Migration, 2002, Department of Economic and Social Affairs, Population Division (New York: United Nations). Also available via the Internet at: http://www.un.org/esa/population/publications/ittmig2002/ittmig2002.htm

Van Groezen, Bas, and Theo Leers, 2000, "The Effects of Asymmetric Demographic Shocks with Perfect Capital Mobility,” Working Paper, Department of Economics (Netherlands: Tilburg University).

World Bank, 2003, World Development Indicators, 2003 CD-ROM (Washington). 